\title{
Boon or bane? On productivity and environmental regulation
}

\author{
Philipp R. Steinbrunner ${ }^{1}[$
}

Received: 13 April 2021 / Accepted: 25 August 2021 / Published online: 8 September 2021

(c) The Author(s) 2021

\begin{abstract}
As climate change has gained more attention in the last decade, effects of environmental regulation on productivity are important to design green tax reforms. This study examines the impacts of environmental taxes and spillovers on technical efficiency, using data on Central European manufacturing firms, from 2009 to 2017. The results highlight strong effects of environmental taxation on productivity. Besides, downstream energy taxation does not affect productivity, while upstream taxes decrease technical efficiency. Downstream pollution taxation decreases productivity, whereas upstream taxation spurs technical efficiency. This study contributes to the literature by investigating heterogeneous tax effects across industries, involving tax spillovers and considering endogeneity issues.
\end{abstract}

Keywords Economic regulation · Environmental taxes and subsidies

JEL Classification L51 $\cdot$ H23

\section{Introduction}

The choice of environmental policy instruments has been extensively debated since the seminal contribution of Pigou (1920) on using taxes and subsidies to internalize welfare losses caused by externalities. The environmental economics literature distinguishes between 'command and control' (CAC) approaches (e.g. environmental protection amendments) and 'market based incentives' (MBI) (e.g. environmental taxes, tradable permits). Although economic theory preferred MBIs because of their cost effectiveness, CAC has been the major instrument for a long time. During the 1990s, MBIs became more popular, i.e. environmental taxes in the beginning of

Philipp R. Steinbrunner

philipp.steinbrunner@unito.it

1 Department of Economics, Social Studies, Applied Mathematics and Statistics, School of Management and Economics, University of Turin, Corso Unione Sovietica 218/bis, 10134 Torino, TO, Italy 
the 1990s and tradable permits in the late 1990s (e.g. the Kyoto protocol in 1997) (Norregaard and Reppelin-Hill 2000). Currently, environmental taxes are enjoying a renaissance (Krukowska 2020).

While almost every microeconomic textbook covers the basic models of environmental policy's welfare implications in first-best and second-best worlds, economic theory and empirical evidence on its effects on firm behaviour and performance are sparse and provide conflicting guidance, though being fundamental for designing green tax reforms. First, the 'pollution haven hypothesis' claims that firms relocate to countries with weak environmental standards when environmental taxes rise, reducing profits, productivity and inputs by limiting production possibilities (Commins et al. 2011). Conversely, the 'factor endowment hypothesis' suggests that employing available clean natural resources improves production possibilities and productivity (Copeland and Taylor 2004). Similarly, the 'Porter hypothesis' asserts that environmental regulation spurs firms to innovate, increasing productivity and investment (Porter 1991; Porter and Van der Linde 1995). To provide empirical evidence on these conflicting hypothesis, I examine the impacts of environmental taxes on company performance and behaviour employing micro-data on Central European manufacturing firms from 2009 to 2017.

Many empirical studies examine the environmental benefits of climate policies, while only few studies, primarily undertaken at country- or industry-level, analyse impacts of environmental policy on firm behaviour. Leiter et al. (2011) investigate effects of industry expenditure on environmental protection and country-level environmental tax revenue on firm investment, and find positive, but diminishing effects. Enevoldsen et al. (2007) estimate responses of competitiveness and output to energy taxes and find significantly negative impacts, whereas Henderson and Millimet (2005) observe insignificant impacts of environmental stringency on statelevel output. Next, Aziz et al. (2021) conclude that environmental policy stringency negatively affects economic growth in the short-run, but positively in the long run. Besides, Franco and Marin (2017) investigate how environmental tax rates and their spillovers affect innovation and efficiency.

Conversely, only few studies employ firm-level data. Fujii et al. (2016) identify technical innovators in the area of $\mathrm{CO}_{2}$ emissions using Chinese firm-level data. Martin et al. (2014) observe insignificant effects of carbon taxation on British manufacturing firms' employment, gross output and productivity, and observe significantly negative impacts on energy intensity and electricity use. Similarly, Yang et al. (2021) find significantly negative effects of tightening $\mathrm{SO}_{2}$ removal rates on Chinese firm- and industry-level productivity. In contrast, Commins et al. (2011) find positive effects of energy taxes on productivity and returns on capital, negative impacts on employment, and mixed effects on investment of European firms. Broberg et al. (2013) regress Swedish manufacturing firms' productivity on distributed lags of investment in pollution control and prevention, rejecting the Porter hypothesis. Supporting the Porter hypothesis, Lanoie et al. (2008) find negative short-run and positive long-run impacts of environmental policy stringency on technical efficiency of Quebec's manufacturing firms. Managi et al. (2005) investigate the impact of environmental policy on technical efficiency of the offshore oil and gas industry and confirm the Porter hypothesis. Last, Lundgren et al. (2015) estimate the efficiency 
impacts of $\mathrm{CO}_{2}$ taxes on Swedish pulp and paper manufacturers, partially observing significantly positive effects.

This work contributes to the available literature in several aspects. First, my dataset also covers smaller firms next to large or listed firms enabling a more comprehensive analysis. Second, I allow heterogeneous effects of environmental tax rates across industries. Third, to the best of my knowledge, this is the first study examining downstream and upstream environmental tax spillovers using firm-level data. Fourth, I consider endogeneity of environmental tax rates by employing lags instead of contemporaneous values.

Generally, energy and pollution tax rates significantly impact productivity in many industries. Positive impacts of taxes on productivity are observed in energyintensive sectors, industries producing energy-consuming goods and polluting sectors, whereas negative impacts are estimated in industries declining in Europe. Conversely, input amounts significantly respond in fewer industries. Downstream energy tax rates do not affect productivity, while upstream ones decrease technical efficiency. Downstream pollution taxation decreases productivity, whereas upstream taxation spurs technical efficiency.

The paper proceeds as follows: Sect. 2 introduces the empirical framework and data, used to examine the impacts of environmental regulation on firm behaviour, while Sect. 3 provides the results of the production function estimations and the regressions of firm behaviour. Last, Sect. 4 sums up and draws conclusions.

\section{Empirical strategy and data}

\subsection{First stage: estimation of the production function}

To establish links between environmental regulation and productivity, a two-stage procedure is employed. Following the literature (e.g. Gemmell et al. 2018; Richter and Schiersch 2017; Collard-Wexler and De Loecker 2015; Lu and Yu 2015; Du et al. 2014; Del Bo and Chiara 2013; Doraszelski and Jaumandreu 2013; Crinò and Epifani 2012; De Loecker and Warzynski 2012; Arnold et al. 2011; De Loecker 2007a; Javorcik 2004), I estimate three-input revenue-based Cobb-Douglas production functions, as described in Eq. (1), with the method by Ackerberg et al. (2015) explained in Appendix 1. $y$ denotes logged output (dependent variable), $k$ logged capital (state variable), $l$ logged labour (free variable), and $m$ logged material (proxy variable). $\zeta$ is the sum of unobserved productivity $\omega$ and measurement errors of productivity shocks $\psi$. Indices $i$ and $t$ represent firms and years. A Cobb-Douglas specification is chosen, as it is probably the most popular type in the literature, although translog specifications are more flexible, though data demanding (Syverson 2011).

$$
y_{i, t}=\beta_{k} \cdot k_{i, t}+\beta_{l} \cdot l_{i, t}+\beta_{m} \cdot m_{i, t}+\underbrace{\omega_{i, t}+\psi_{i, t}}_{\zeta_{i, t}}
$$

As product-level output and input quantities are usually not available, while monetary outputs and inputs are mostly provided as firm-level aggregates, I follow the 
literature and estimate gross output production functions using producers' real total monetary outputs and inputs. Firm-level data are sourced from the Orbis database published by Bureau van Dijk. Orbis contains accounting data, legal form, industry activity codes, and incorporation date for a large set of public and private companies worldwide. I include active and inactive; medium sized, large and very large ${ }^{1}$ European manufacturing companies (NACE C1000-C3320), incorporated in five countries: Austria, the Czech Republic, Hungary, Slovakia and Slovenia. The final sample is a nine-year unbalanced panel dataset, from 2009 to 2017, containing 18,060 firms with 123,101 observations of 24 two-digit NACE industries (94 three-digit and 265 four-digit NACE industries). ${ }^{2}$

Output is defined as real operating revenues, being the sum of net sales, other operating revenues and stock variations excluding VAT (Bureau van Dijk 2007) deflated by annual gross value added deflators from the OECD database, ${ }^{3}$ varying across countries, two-digit NACE industries and years. Next, capital is approximated with tangible fixed assets (e.g. machinery) deflated by uniform investment good price indexes from the same database, ${ }^{4}$ varying across countries and years. Third, labour is a physical measure of the number of employees included in the company's payroll. Fourth, material is measured by real material expenditures, being the sum of expenditures on raw materials and intermediate goods deflated by uniform intermediate good price indexes from the same database, ${ }^{5}$ varying across countries and years. Fifth, real investment is approximated by exploiting the law of motion of capital, i.e. depreciation, deflated by the same price index as capital, and first differences in firm-specific real tangible assets are summed (Castelnovo et al. 2019; Richter and Schiersch 2017; Newman et al. 2015; Du et al. 2014; Nishitani et al. 2014; Baghdasaryan and la Cour 2013; Javorcik and Li 2013; Crinò and Epifani 2012; Higón and Antolín 2012; Javorcik 2004).

To consider heterogenous input elasticities $\beta$ across countries, I follow the majority of studies (e.g. Fons-Rosen et al. 2021; Levine and Warusawitharana 2021; Gemmell et al. 2018; Olper et al. 2016) and estimate Eq. (1) for each two-digit NACE industry-country combination. As productivity is the residual, it measures the shifts in output while keeping inputs constant. Owing to the logged dependent variable, productivity is also logged, as shown in Eq. (2) (Javorcik 2004; Olley and Pakes 1996).

$$
\log \left(\operatorname{TFP}_{i, t}\right)=y_{i, t}-\beta_{k} \cdot k_{i, t}-\beta_{l} \cdot l_{i, t}-\beta_{m} \cdot m_{i, t}
$$

\footnotetext{
${ }^{1}$ Orbis considers firms to be 'medium sized', when operating revenues $\geq 1$ mill. EUR or total assets $\geq 2$ mill. EUR or employees $\geq 15$. Orbis defines firms to be 'large', when operating revenues $\geq 10$ mill. EUR or total assets $\geq 20$ mill. EUR or employees $\geq 150$. Firms are 'very large', when operating revenues $\geq$ 100 mill. EUR or total assets $\geq 200$ mill. EUR or employees $\geq 1000$ or the company is listed (Bureau van Dijk 2007).

2 Observations with implausible output and input values (e.g. negative values, values almost zero), missing values, unknown activity status or industry affiliation are dropped.

3 https://stats.oecd.org/Index.aspx?

4 https://stats.oecd.org/Index.aspx?DataSetCode=MEI_PRICES_PPI

5 https://stats.oecd.org/Index.aspx?DataSetCode=MEI_PRICES_PPI
} 


\subsection{Second stage: determinants of firm behaviour}

In the second stage, I examine the effects of environmental policy on firm behaviour. Instead of employing first-differencing as Commins et al. (2011), I use fixed effects regressions, as described in Eq. (3), primarily used in the literature (e.g. Castelnovo et al. 2019; Franco and Marin 2017). The indices $i, t, s$ and $c$ denote firms, years, two-digit NACE industries and countries, with $S$ and $C$ being the total numbers of two-digit NACE industries and countries. $e$ and $p$ represent the energy and pollution tax rates.

$$
\begin{aligned}
w_{i, t}= & \sum_{s=1}^{S} \delta_{e, s} \cdot D_{s} \cdot \text { energy tax } \operatorname{rate}_{c, s, t-2} \\
& +\sum_{s=1}^{S} \delta_{p, s} \cdot D_{s} \cdot \text { pollution tax } \operatorname{rate}_{c, s, t-2} \\
& +\phi_{e} \cdot \text { downstream energy tax } \operatorname{rate}_{c, s, t-2}+\rho_{e} \cdot \text { upstream energy tax rate } \\
& +\phi_{p} \cdot \text { downstream pollution tax } \operatorname{rate}_{c, s, t-2}+\rho_{p} \cdot \text { upstream pollution tax } \text { rate }_{c, s, t-2} \\
& +\beta \cdot X_{c, i, s, t-1}+\alpha_{i}+\sum_{c=1}^{c} \sum_{t=2010}^{2017} \gamma_{c, t} \cdot D_{c} \cdot D_{t}+\epsilon_{i, t}
\end{aligned}
$$

The dependent variables, $w$, cover logged productivity, real investment, real material expenditures and employment. Tax rates are introduced in levels to avoid losing zero-value observations when logging them (Franco and Marin 2017; Lundgren et al. 2015). Like Commins et al. (2011), I estimate the effects of energy and pollution tax rates for each two-digit NACE industry by interacting them with dummies for two-digit NACE industries $D_{s}$. Table 3 in Appendix 2 lists all two-digit NACE industries' codes and names. Given the log-level representation, coefficients $\delta_{e, s}$ and $\delta_{p, s}$ quantify the dependent variables' environmental tax rate semi-elasticities for each two-digit NACE industry.

I source data on energy and pollution tax revenues starting from 2008, in Euro, from Eurostat (Franco and Marin 2017; Commins et al. 2011) ${ }^{67}$ Energy taxes cover taxes on energy production and products (e.g. petrol; diesel; electricity; biofuels; $\mathrm{CO}_{2}$, etc.), while pollution taxes include taxes related to emissions to air and water, management of waste and noise (e.g. $\mathrm{NO}_{\mathrm{X}} ; \mathrm{SO}_{\mathrm{X}}$; other emissions (excluding $\mathrm{CO}_{2}$ ); pesticides; artificial fertilisers; packaging etc.) (Eurostat 2020). Resource and transport taxes are excluded due to multicollinearity. Tax revenues, varying across countries, two-digit NACE industries and years, are divided by nominal gross values

\footnotetext{
${ }^{6}$ https://appsso.eurostat.ec.europa.eu/nui/show.do?dataset=env_ac_taxind2\&lang=en

${ }^{7}$ Generally, environmental tax rates, control variables, value added deflators and symmetric input-output tables are aggregated at the country and two-digit NACE industry-level. For some industries, however, data are only available at a higher-order group-level, i.e. for the industries C10, C11 and C12, the covariates are only available as a sum across the three industries. The same holds for the industries C13$\mathrm{C} 15$ and $\mathrm{C} 31-\mathrm{C} 32$.
} 
added from the same database, ${ }^{8}$ varying at the same level, to compute average tax rates (Franco and Marin 2017; Commins et al. 2011).

Following Franco and Marin (2017), I involve tax rates paid by all downstream and upstream industries (including agriculture, mining, services) ${ }^{9}$ of the same country, since governments try to homogenize tax rates to avoid capital flights. Downstream spillovers are defined as weighted averages of tax rates paid by downstream sectors. I construct the weights from symmetrical input-output tables of the year $2010^{10}$ provided by Eurostat (Du et al. 2014). ${ }^{11}$ For each country, the weighting matrix is calculated as follows: First, the main diagonal is set to zero to avoid double counting and multicollinearity. Second, matrices are row-normalized to obtain weights for every two-digit NACE industry-country combination. Third, they are multiplied with the country-specific tax rate vectors. Conversely, upstream tax rates define weighted averages of environmental tax rates paid by suppliers and are calculated analogously, except that the matrix's transpose is row-normalized. Like Franco and Marin (2017), regulations embodied in imports and exports are excluded, as matrices only cover domestic flows. Tax spillovers are not interacted with industry dummies to avoid multicollinearity.

Concerning endogeneity, two issues are worth discussing: First, endogeneity may be caused by reverse causality. Although the literature (e.g. Franco and Marin 2017; Broberg et al. 2013; Commins et al. 2011; Lanoie et al. 2008; Managi et al. 2005) usually employs distributed lags (including contemporaneous values) of environmental policy stringency (e.g. taxes, pollution abatement control expenditures, emissions) treating them as exogenous, governments set tax rates to affect firms' future production processes. To overcome this problem, Franco and Marin (2017) involve environmental taxes lagged by one year arguing that, in contrast to emissions and pollution abatement control expenditures, governments set environmental tax rates exogenously. Since lagging tax rates by one year might still not suffice, I lag tax rates by two years to break reverse causality. Second, I introduce important drivers of reorganization within firms, firm-level fixed effects and nested country-year dummies to solve omitted variable biases implied by confounding factors.

If environmental tax rates affect productivity and inputs negatively, the pollution haven hypothesis is supported. Contrarily, positive effects of environmental regulation on productivity and investment favour the Porter hypothesis. Last, the factor endowment hypothesis suggests positive impacts on productivity due to reorganization of production processes (Commins et al. 2011).

\footnotetext{
${ }^{8}$ https://appsso.eurostat.ec.europa.eu/nui/show.do?dataset=nama_10_a64\&lang=de

${ }^{9}$ Due to missing values in the weighting matrices, sectors L, T and U, and industry G47 are excluded. For some industries, data are only available at the sector-level (B, D, F, I, O, P) or group-level (C10-C12, C13-C15, C31-C33, E37-E39, J59-J60, J62-J63, M69-M70, M74-M75, N80-N82, Q87-Q88, R90R92).

10 Annual data are only provided for Austria, while for the countries data are supplied every five years. This might be a minor issue, as weights obtained for Austria are quite constant across years. Furthermore, country-specific weights constructed from the 2010s and 2015s tables are similar.

11 https://appsso.eurostat.ec.europa.eu/nui/show.do?dataset=naio_10_cp1700\&lang=de
} 
Vector $X$ introduces control variables, capturing other drivers of technological progress and reorganization within firms. They are lagged by one period to overcome reverse causality (Franco and Marin 2017; Inui et al. 2012). ${ }^{12}$ As employment also responds to wage costs, labour market regulation and human capital, I involve logged firm-level average real wages (Del Bo 2013). In comparison, Commins et al. (2011) employ shares of aggregate labour costs in value added and Franco and Marin (2017) logged industry-specific average wages, but they suffer from multicollinearity. Data on firm-level wage costs are obtained from Orbis, deflated by country-level HCPIs sourced from Eurostat ${ }^{13}$ and divided by firm-level employment. Given these studies, I expect them to affect productivity positively, as more human capital makes firms more productive, and employment negatively due to higher costs.

Besides, I introduce two variables capturing the degrees of foreign and domestic competition. First, I include import penetration (Commins et al. 2011), varying across countries, two-digit NACE industries and years. As databases only provide country-level data, I approximate industry-specific pendants with shares of imports in the total supply of goods. The latter is defined as the sum of foreign (imports) and domestic supply (value added). Data on two-digit NACE industry-specific imports, denoted in US dollar, are obtained from the OECD database ${ }^{14}$ and converted to Euro employing exchange rates from the Austrian National Bank. ${ }^{1516}$ Second, I involve inverted Herfindahl-Hirschman indexes (HHI), $1-H H I$ and their squares (Atayde et al. 2021; Aghion et al. 2015). Franco and Marin (2017) introduce the share of firms with more than 250 employees, but OECD data suffer from missing observations. I calculate the variable, being a number between zero (monopoly) and one (perfect competition), from firm-level real operating revenues for every country, three-digit NACE industry and year. Given the literature (e.g. Inui et al. 2012; Van Reenen 2011; Aghion et al. 2005), I expect a concave relationship, as fiercer competition spurs firms to innovate, but also discourages innovation by deteriorating postentry rents.

Furthermore, I include fixed effects for firms $\alpha_{i}$, capturing unobserved firm-level heterogeneity (e.g. country, NACE industry, company size, legal form). Unlike including country-level controls as Commins et al. (2011), I involve nested country-year dummies $D_{c} \cdot D_{t}$, capturing these countrywide shocks (e.g. profit taxes, electricity and fuel prices, institutional quality, business activity).

\footnotetext{
12 Relevant variables are usually influenced by contemporaneous productivity, i.e. short-run rises in productivity will decrease imports and intensify competition in the same year, as they are newly determined every year.

13 https://appsso.eurostat.ec.europa.eu/nui/show.do?dataset=prc_hicp_aind\&lang=de

14 https://stats.oecd.org/Index.aspx?DataSetCode=TEC1_REV4\#

15 https://www.oenb.at/isaweb/report.do;jsessionid=31BAE0E7828A28A2607F23FE67871C76?report= 2.14 .5

16 Though data is available for all two-digit NACE industries, imports are aggregated at the same level as GDP to calculate shares. For the group C11-C13, C13 is excluded due to missing values.
} 


\section{Results}

In the first stage, I estimate production functions to construct productivity for every firm and year, while, in the second stage, I regress $\log (T F P)$ and other dependent variables using fixed effects models. Summary statistics are shown in Table 4 in Appendix 3.

\subsection{Estimation of the production function}

Tables 5-9 in Appendix 4 summarize the results of the production function estimations for each two-digit NACE industry-country combination. In every table, columns (1)-(3) provide the elasticities of output with respect to the considered inputs. Columns (4) and (5) display the numbers of observations and firms. The sum of input elasticities supplies an estimate of the degree of returns to scale. Therefore, column (6) shows the $p$-value of the Wald tests examining whether this sum significantly differs from one (constant returns to scale). In some industries, too few firms exit the market not allowing to consider attrition. Column (7), thus, provides information on whether attrition can be and is considered or not. ${ }^{17}$

Overall, results are consistent with the literature (e.g. Richter and Schiersch 2017; Lu and Yu 2015; Du et al. 2014; Arnold et al. 2011). Labour elasticities mostly vary between 0.20 and 0.40 (Richter and Schiersch 2017; Arnold et al. 2011). In some industries, coefficients lie between 0.05 and 0.20 as in $\mathrm{Lu}$ and $\mathrm{Yu}$ (2015) and $\mathrm{Du}$ et al. (2014). As in these studies, capital elasticities are usually small between 0 and 0.10. In Hungary, some of them, however, are larger, suggesting that the relevant industries produce more capital-intensively. Depending on the study, material elasticities vary between 0.40 and 0.90 , confirming my results.

Nevertheless, there are some abnormalities. Particularly, three coefficients exceed one (Austria C23; Slovenia C14) and, similarly to Lu and Yu (2015), the elasticity of capital falls below zero in eight (Austria C18, C24 and C28; Czech Republic C18 and C30; Hungary C16; Slovakia C26; Slovenia C33).

\subsection{Effects of environmental taxes and spillovers}

Tables 1 and 2 display the estimates of equation (3). Columns (1)-(4) show the results of the regressions of logged productivity, real investment, real material expenditures and employment. Standard errors are clustered at the firm-level to overcome residual serial correlation. ${ }^{18}$

The first block of Table 1 displays energy tax rate semi-elasticities for each twodigit industry, $\delta_{e, s}$, the second block those for the pollution tax rate, $\delta_{p, s}$. Given the

\footnotetext{
${ }^{17}$ I exclude tobacco (C12) and coke and petroleum (C19) industries because of too few observations. Industries with less than 15 firms whose analysis does not allow to consider attrition are also dropped due to not-meaningful results.

18 To check whether results are driven by industries with abnormal production function estimates, I exclude relevant industry-country combinations. The results, however, barely change.
} 
Table 1 Results of the fixed effects regressions (I)

Dependent Variable:

$\log ($ TFP $) \quad \log ($ Real Investment $) \quad \log ($ Real Material Expenditures $) \quad \log ($ Employment $)$

(1)

(2)

(3)

(4)

\begin{tabular}{|c|c|c|c|c|}
\hline \multicolumn{5}{|l|}{$\delta_{e, s}$} \\
\hline C10 & $\begin{array}{l}-0.1407 * * * \\
(0.0090)\end{array}$ & $\begin{array}{l}0.0581 \\
(0.0575)\end{array}$ & $\begin{array}{l}-0.0422 * * \\
(0.0207)\end{array}$ & $\begin{array}{l}-0.0984 * * * \\
(0.0205)\end{array}$ \\
\hline C11 & $\begin{array}{l}-0.1535 * * * \\
(0.0357)\end{array}$ & $\begin{array}{l}-0.0444 \\
(0.0975)\end{array}$ & $\begin{array}{l}-0.0457 \\
(0.0552)\end{array}$ & $\begin{array}{l}-0.0583 \\
(0.0500)\end{array}$ \\
\hline C13 & $\begin{array}{l}0.0030 \\
(0.0273)\end{array}$ & $\begin{array}{l}0.0792 \\
(0.2023)\end{array}$ & $\begin{array}{l}0.0919 \\
(0.0755)\end{array}$ & $\begin{array}{l}0.0827 \\
(0.0526)\end{array}$ \\
\hline C14 & $\begin{array}{l}-0.1081 * \\
(0.0602)\end{array}$ & $\begin{array}{l}-0.0872 \\
(0.2489)\end{array}$ & $\begin{array}{l}-0.0860 * \\
(0.0513)\end{array}$ & $\begin{array}{l}-0.0388 \\
(0.0402)\end{array}$ \\
\hline C15 & $\begin{array}{l}0.0174 \\
(0.0305)\end{array}$ & $\begin{array}{l}0.1893 \\
(0.3477)\end{array}$ & $\begin{array}{l}0.1200 * \\
(0.0691)\end{array}$ & $\begin{array}{l}-0.0023 \\
(0.0559)\end{array}$ \\
\hline C16 & $\begin{array}{l}0.0680 * * * \\
(0.0072)\end{array}$ & $\begin{array}{l}-0.0748 \\
(0.0563)\end{array}$ & $\begin{array}{l}0.0101 \\
(0.0185)\end{array}$ & $\begin{array}{l}-0.0137 \\
(0.0170)\end{array}$ \\
\hline C17 & $\begin{array}{l}0.0030 \\
(0.0085)\end{array}$ & $\begin{array}{l}0.0544 \\
(0.0443)\end{array}$ & $\begin{array}{l}0.0012 \\
(0.0175)\end{array}$ & $\begin{array}{l}0.0128 \\
(0.0139)\end{array}$ \\
\hline C18 & $\begin{array}{l}-0.4815 * * * \\
(0.0816)\end{array}$ & $\begin{array}{l}-0.9274 * * * \\
(0.3433)\end{array}$ & $\begin{array}{l}-0.0451 \\
(0.1526)\end{array}$ & $\begin{array}{l}0.1374 \\
(0.1022)\end{array}$ \\
\hline $\mathrm{C} 20$ & $\begin{array}{l}0.0057 * * * \\
(0.0013)\end{array}$ & $\begin{array}{l}-0.0059 \\
(0.0048)\end{array}$ & $\begin{array}{l}0.0040 * * \\
(0.0019)\end{array}$ & $\begin{array}{l}0.0012 \\
(0.0019)\end{array}$ \\
\hline $\mathrm{C} 21$ & $\begin{array}{l}-0.4853 * * * \\
(0.0902)\end{array}$ & $\begin{array}{l}1.2435 * * \\
(0.6142)\end{array}$ & $\begin{array}{l}0.1549 \\
(0.2385)\end{array}$ & $\begin{array}{l}0.1106 \\
(0.2074)\end{array}$ \\
\hline $\mathrm{C} 22$ & $\begin{array}{l}0.1156^{* * * *} \\
(0.0078)\end{array}$ & $\begin{array}{l}0.0088 \\
(0.0411)\end{array}$ & $\begin{array}{l}-0.0134 \\
(0.0172)\end{array}$ & $\begin{array}{l}-0.0048 \\
(0.0141)\end{array}$ \\
\hline $\mathrm{C} 23$ & $\begin{array}{l}0.0348 * * * \\
(0.0072)\end{array}$ & $\begin{array}{l}-0.0042 \\
(0.0367)\end{array}$ & $\begin{array}{l}0.0015 \\
(0.0240)\end{array}$ & $\begin{array}{l}-0.0158 \\
(0.0129)\end{array}$ \\
\hline $\mathrm{C} 24$ & $\begin{array}{l}0.0013 \\
(0.0016)\end{array}$ & $\begin{array}{l}-0.0085 \\
(0.0105)\end{array}$ & $\begin{array}{l}0.0053 \\
(0.0043)\end{array}$ & $\begin{array}{l}0.0012 \\
(0.0031)\end{array}$ \\
\hline $\mathrm{C} 25$ & $\begin{array}{l}0.2461 * * * \\
(0.0178)\end{array}$ & $\begin{array}{l}0.0236 \\
(0.0783)\end{array}$ & $\begin{array}{l}0.0659 * \\
(0.0363)\end{array}$ & $\begin{array}{l}0.1166^{* * * *} \\
(0.0296)\end{array}$ \\
\hline C26 & $\begin{array}{l}0.8195 * * * \\
(0.0830)\end{array}$ & $\begin{array}{l}0.9244 * * \\
(0.4632)\end{array}$ & $\begin{array}{l}0.1707 \\
(0.1893)\end{array}$ & $\begin{array}{l}0.0182 \\
(0.1276)\end{array}$ \\
\hline $\mathrm{C} 27$ & $\begin{array}{l}0.1128 * * \\
(0.0472)\end{array}$ & $\begin{array}{l}-0.1525 \\
(0.2846)\end{array}$ & $\begin{array}{l}-0.0458 \\
(0.1154)\end{array}$ & $\begin{array}{l}-0.0068 \\
(0.0716)\end{array}$ \\
\hline C28 & $\begin{array}{l}0.1940 * * * \\
(0.0241)\end{array}$ & $\begin{array}{l}-0.1628 \\
(0.1444)\end{array}$ & $\begin{array}{l}0.0273 \\
(0.0620)\end{array}$ & $\begin{array}{l}0.0150 \\
(0.0432)\end{array}$ \\
\hline C29 & $\begin{array}{l}0.0140 * * * \\
(0.0043)\end{array}$ & $\begin{array}{l}0.0384 \\
(0.0276)\end{array}$ & $\begin{array}{l}0.0300 * \\
(0.0168)\end{array}$ & $\begin{array}{l}-0.0052 \\
(0.0109)\end{array}$ \\
\hline C30 & $\begin{array}{l}-0.1224 * * * \\
(0.0339)\end{array}$ & $\begin{array}{l}0.0355 \\
(0.1630)\end{array}$ & $\begin{array}{l}-0.0233 \\
(0.0752)\end{array}$ & $\begin{array}{l}0.0066 \\
(0.0654)\end{array}$ \\
\hline
\end{tabular}


Table 1 (continued)

Dependent Variable:

$\log ($ TFP $) \quad \log ($ Real Investment $) \quad \log ($ RealMaterial Expenditures $) \quad \log ($ Employment $)$

(1)

C31 -

$\mathrm{C} 32$

(0.0561) (0.4275)

0.3883

$-0.1452$

(0.3689)

C33 $-0.0453 *$

$-0.2049$

(0.0256)

(0.1313)

$\delta_{p, s}$

$\mathrm{C} 10$

$\begin{array}{ll} & (0.0035) \\ \mathrm{C} 11 & 0.0362 * * * \\ & (0.0117)\end{array}$

$-0.0496 * *$

(0.0200)

C13 0.3184***

$-0.0962 *$

(0.0510)

(0.1152)

$-0.2249$

(0.7016)

C14

$0.7623^{* *}$

$1.4917 * *$

(0.3023)

(0.6967)

C15

$0.3614^{* * * *}$

0.3004

(0.1363)

(0.8660)

C16-0.0145***

0.0042

(0.0044)

(0.0348)

C17 0.0001

(0.0010)

0.0045

C18 0.0258***

(0.0075)

(0.0043)

$-0.0242$

$\mathrm{C} 20 \quad 0.0154^{* * * *}$

(0.0268)

(0.0038)

$-0.0167$

(0.0214)

C21 -0.1195

(0.1603)

$-1.2157$

(1.1372)

C22 $0.0167 * * *$

0.0045

(0.0039)

(0.0222)

C23 0.0109

(0.0067)

0.0440

(0.0693)

$\mathrm{C} 24 \quad 0.0105^{* * * *} \quad 0.0110$

(0.0037) (0.0256)

C25 -0.6258 ***

$-0.5536 *$

(0.0594)

(0.3154)

C26 0.0053

(0.0054)

0.0136

(0.0326)

C27 -0.3693 ***

0.1646

(0.0358)

(0.2863)
(3)

$\begin{array}{ll}0.1100 & -0.1431 \\ (0.1288) & (0.1165) \\ -0.0157 & 0.1516 \\ (0.1777) & (0.1455) \\ -0.0851 & -0.0074 \\ (0.0535) & (0.0357)\end{array}$

$-0.0208 * *$

0.0004

(0.0096)

(0.0075)

$-0.0224$

$-0.0011$

(0.0130)

$0.4428 *$

(0.2539)

(0.3084)

0.4732 ***

(0.1795)

0.0784

(0.2212)

0.0106

(0.0120)

0.0003

(0.0014)

$-0.0196 * * *$

(0.0056)

0.0073

(0.0062)

0.4281

(0.3277)

0.0004

(0.0078)

$0.0396 * * *$

(0.0106)

0.0004

(0.0075)

$-0.5513 * * *$

(0.0987)

0.0043

(0.0096)

0.0681

(0.0604) 
Table 1 (continued)

Dependent Variable:

$\begin{array}{lll}\log (\text { TFP }) \quad \log (\text { Real Investment }) & \log (\text { Real Material Expenditures }) & \log (\text { Employment })\end{array}$

(1)

\begin{tabular}{lllll}
\hline C28 & $0.0143 * * *$ & -0.0066 & 0.0154 & 0.0099 \\
& $(0.0046)$ & $(0.0406)$ & $(0.0120)$ & $(0.0064)$ \\
C29 & $0.0639^{* * *}$ & 0.0916 & 0.0284 & 0.0049 \\
& $(0.0091)$ & $(0.0824)$ & $(0.0266)$ & $(0.0161)$ \\
C30 & 0.0307 & 0.2138 & $0.4636^{*}$ & 0.1424 \\
& $(0.0961)$ & $(0.6451)$ & $(0.2449)$ & $(0.1869)$ \\
C31 & $0.0310^{* * *}$ & 0.0019 & -0.0155 & 0.0092 \\
& $(0.0063)$ & $(0.0536)$ & $(0.0172)$ & $(0.0148)$ \\
C32 & $0.0191 *$ & 0.0317 & 0.0349 & -0.0221 \\
& $(0.0108)$ & $(0.0473)$ & $(0.0230)$ & $(0.0149)$ \\
C33 & -0.0622 & -0.0040 & -0.0586 & -0.0542 \\
& $(0.0388)$ & $(0.1595)$ & $(0.0651)$ & $(0.0597)$ \\
\hline
\end{tabular}

small values, pollution tax rates are denoted in per mill. In column (1), the energy tax rate semi-elasticity in industry $\mathrm{C} 16$ equals 0.0680 , meaning that productivity increases by $6.80 \%$, when energy tax rates increase by one percentage point. In the same column, the pollution tax rate semi-elasticity in industry $\mathrm{C} 16$ is -0.0145 , suggesting that productivity declines by $1.45 \%$, when the pollution tax rate increases by one per mill. Figures 1, 2, 3, 4 illustrate them graphically. Dots represent the point estimate, lines the $95 \%$-confidence intervals and stars the significance levels. The first block of Table 2 shows the effects of tax spillovers, $\phi$ and $\rho$, and the last block the controls' effects. Small values of energy tax rates are found in the industries $\mathrm{C} 10-\mathrm{C} 11, \mathrm{C} 13-\mathrm{C} 15, \mathrm{C} 18, \mathrm{C} 21-\mathrm{C} 22, \mathrm{C} 25-\mathrm{C} 28$ and $\mathrm{C} 30-\mathrm{C} 33$ with means and maximum values mostly below 0.5 and one percentage point, sometimes resulting in larger coefficients. For these industries, interpreting the coefficients as effects of a rise by one per mill or one-tenth of a per mill $(\mathrm{C} 18, \mathrm{C} 21, \mathrm{C} 26-\mathrm{C} 27)$ is more adequate, i.e. if the energy tax rate in industry $\mathrm{C} 10$ increases by one per mill, dependent variables change by $-1.41,0.58,-0.42$ and $-0.98 \%$. Pollution tax rates' coefficients are higher in $\mathrm{C} 13-\mathrm{C} 15, \mathrm{C} 21, \mathrm{C} 25, \mathrm{C} 27$ and $\mathrm{C} 30$ with means and maximum values mostly below $0.07-0.3$ and 0.7 per mill, suggesting an interpretation as the effects of an increase by one-tenth of a per mill or a smaller unit (C13-C16, C21, C25-C28, $\mathrm{C} 30, \mathrm{C} 33)$, i.e. if the pollution tax rate in industry $\mathrm{C} 13$ rises by one-tenth of a per mill, dependent variables change by $3.18,-2.25,-0.75$ and $4.43 \%$.

Raising energy tax rates in the chemicals (C20), metal processing (C25) and motor vehicle (C29) industries results in productivity gains, as firms significantly purchase more material and employment, favoring the factor endowment hypothesis. Keeping input amounts constant, energy tax rates change some other production processes in the wood (C16), rubber and plastics (C22), non-metallic minerals (C23), electrical equipment (C27) and machinery (C28) sectors, supporting 
Table 2 Results of the fixed effects regressions (II)

Dependent variable:

$\overline{\log (\text { TFP }) \quad \log (\text { Real investment })} \log ($ Real Material log(Employment $)$ Expenditures)

(1)

(2)

(3)

(4)

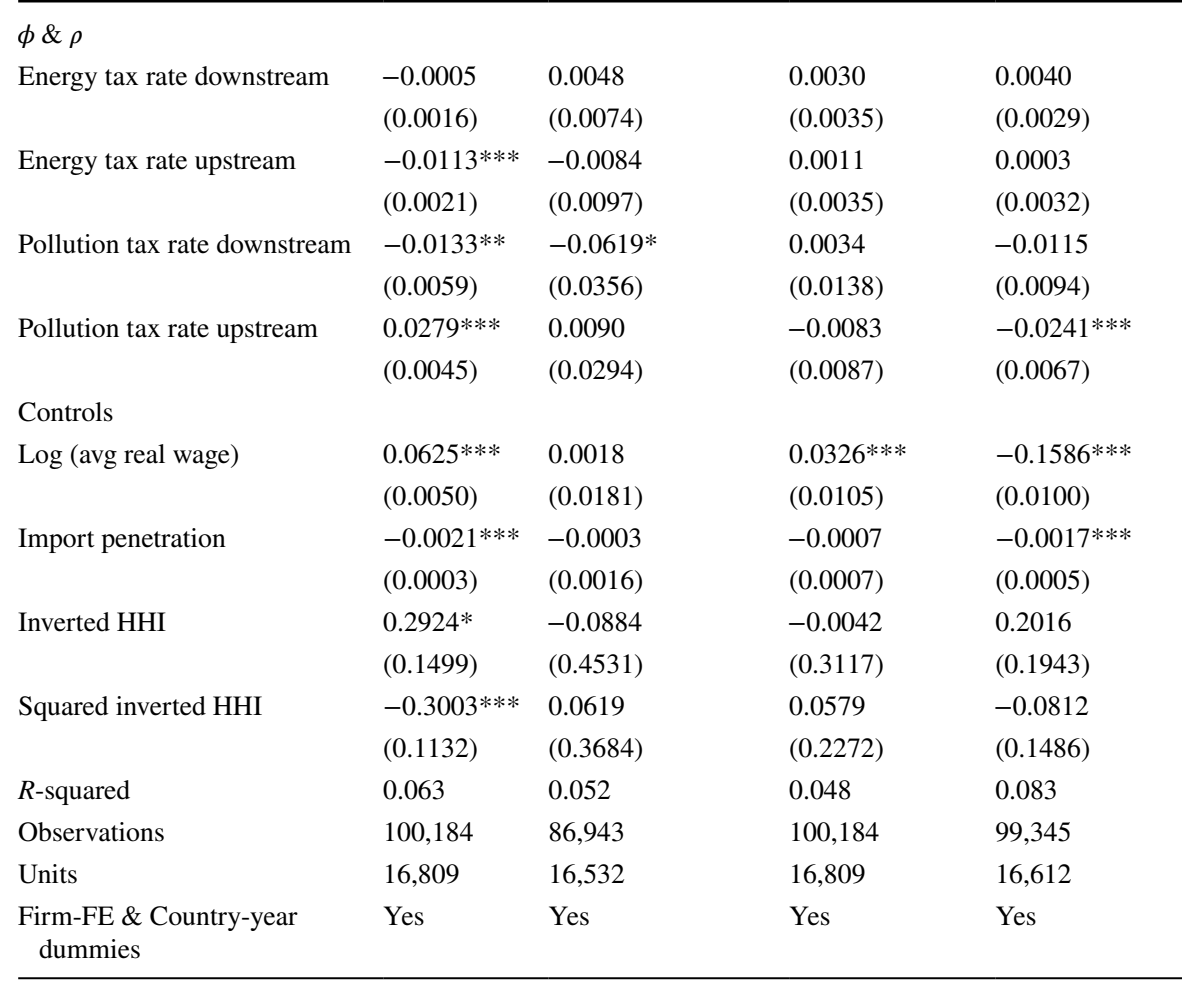

All standard errors, in parenthesis, are clustered at the firm-level. Variance inflation factors (VIFs) are computed manually from the within-R2s of fixed effects regressions of each covariate on the other covariates, firm-level fixed effects and nested country-year dummies, using the data from 2010 to 2017. Observations of 2009 are dropped due to the lagged variables. VIFs of tax rates, varying between 1 and 2 for utmost all variables, do not suggest multicollinearity. Also rejecting multicollinearity, VIFs of the upstream energy and downstream and upstream pollution tax rates, however, are slightly larger around 3.25. On the other hand, the VIFs of the inverted HHI are around 10 due to the inclusion of its squared term suggesting multicollinearity, but decrease severely when excluding its square. For industries C12 and $\mathrm{C} 19$, coefficients are not obtainable, as the both industries suffer from too small sample sizes.

${ }^{*} \mathrm{p}<0.1 ;{ }^{* *} \mathrm{p}<0.05 ;{ }^{* * *} \mathrm{p}<0.01$

the factor endowment hypothesis. Confirming the Porter hypothesis, firms operating in the electronics industry (C26) expand investment and material, implying efficiency gains. Plausibly, these industries benefit from productivity gains, because they operate energy-intensively (C20, C23, C24) or produce energyusing goods (C25-C29). Higher tax rates raise production costs, forcing firms to innovate. Nonetheless, I cannot reject other explanations, as energy taxes can 


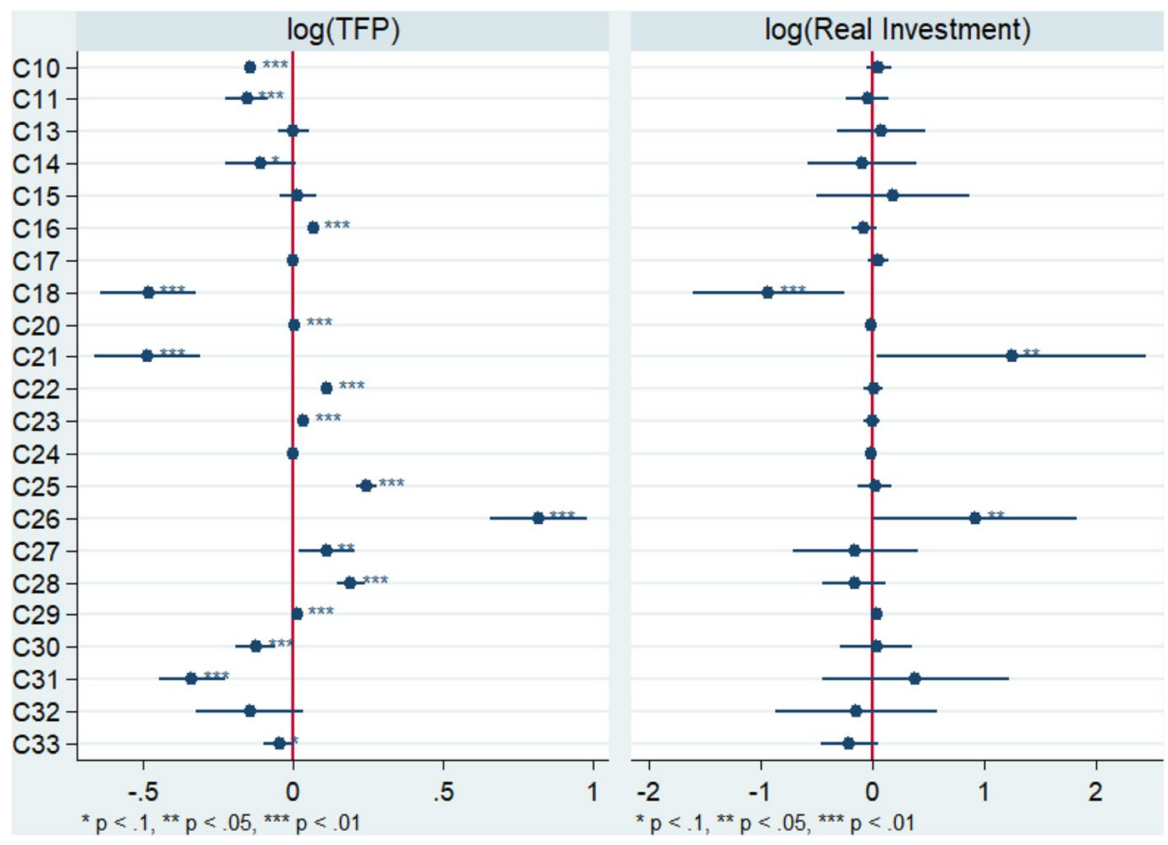

Fig. 1 Impacts of energy tax rates on productivity and real investment by industry

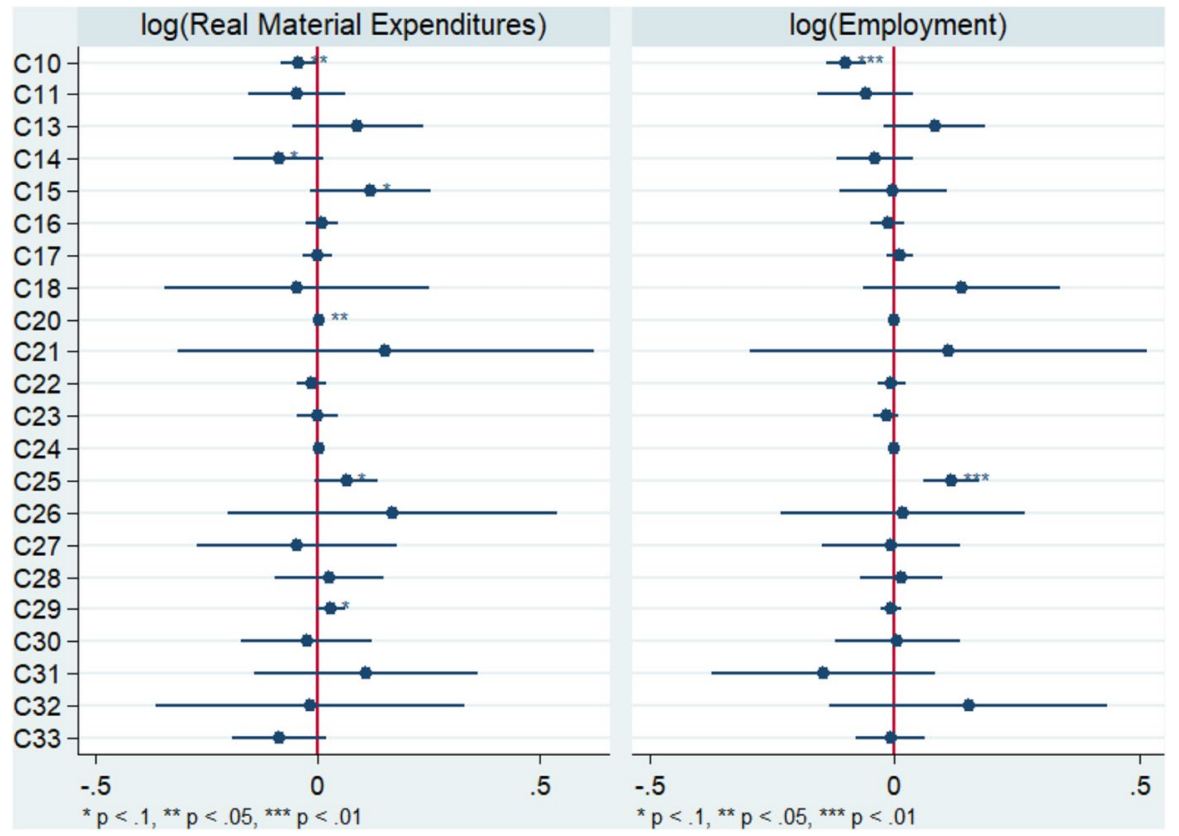

Fig. 2 Impacts of energy tax rates on real material expenditures and employment by industry 


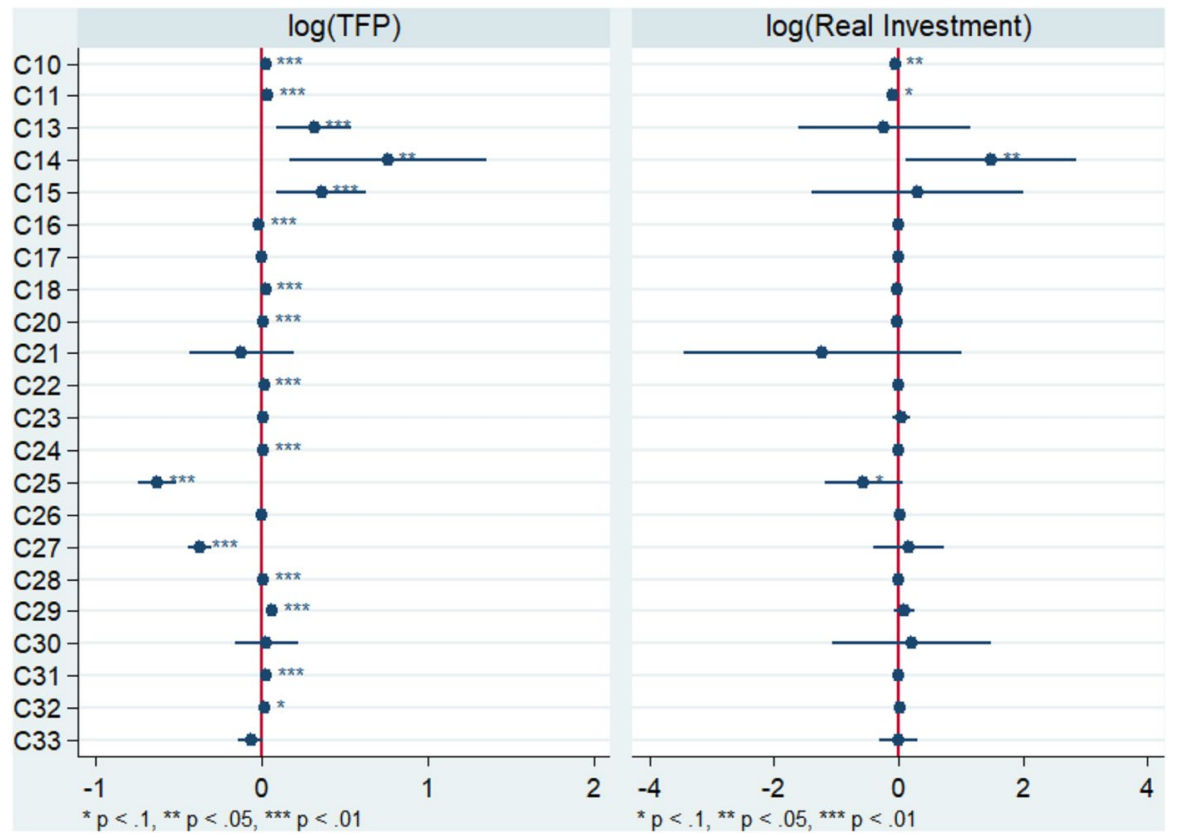

Fig. 3 Impacts of pollution tax rates on productivity and real investment by industry

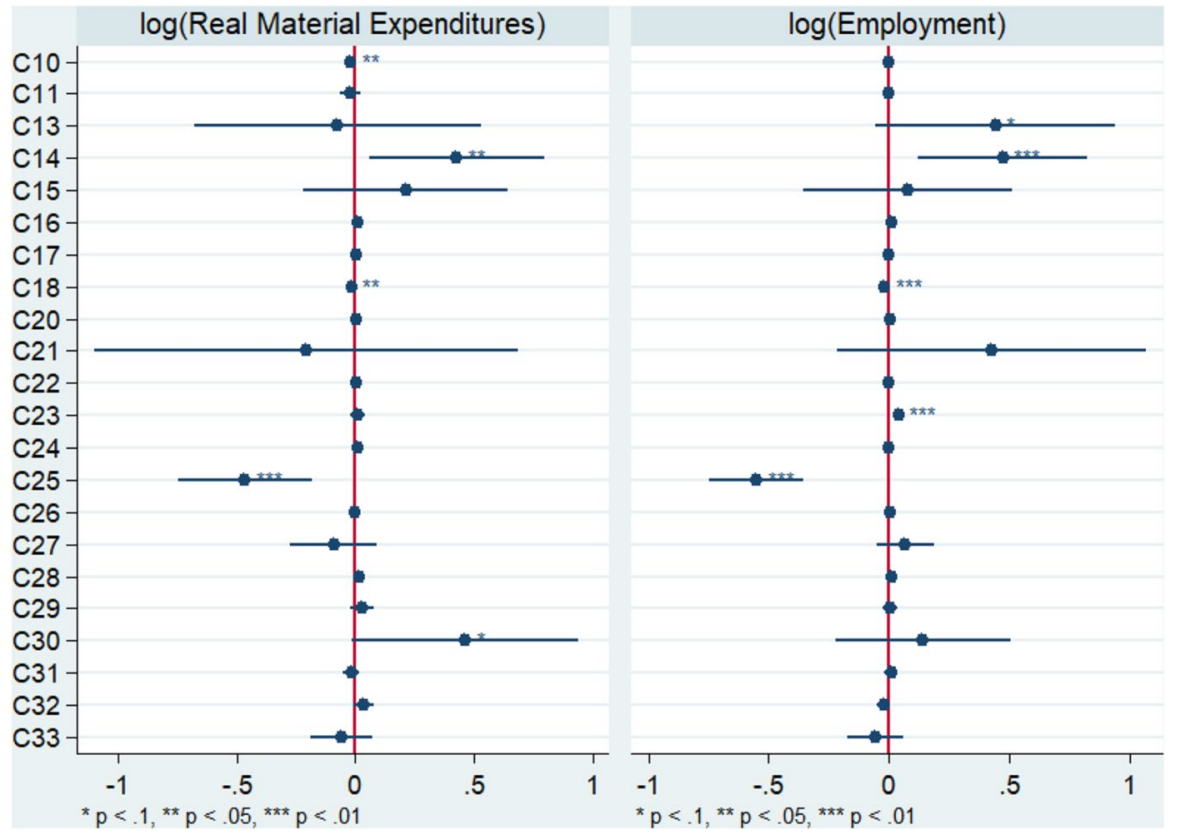

Fig. 4 Impacts of pollution tax rates on real material expenditures and employment by industry 
serve as entry barriers or reduce input price volatility (Yang et al. 2021; Richter and Schiersch 2017; Fujii et al. 2016; Commins et al. 2011).

Higher energy tax rates spur firms to reduce inputs in the food (C10), wearing apparel (C14) and printing and media (C18) industries, causing efficiency losses and, thus, favouring the pollution haven hypothesis. Although the pollution haven hypothesis suggests that environmental policy decreases productivity and input amounts, relocating to other countries is costly. Hence, firms will comply with new regulations by adjusting production processes (e.g. purchasing larger input amounts, substituting inputs with each other), which is observable for the beverages (C11), pharmaceutics $(\mathrm{C} 21)$, other transport equipment $(\mathrm{C} 30)$, furniture $(\mathrm{C} 31)$ and repair and installation (C33) industries. Relevant sectors are declining in Europe (C14, C21, C30-C31), spurring this trend, or produce energy-intensively, but are not able to sufficiently reduce energy intensity (C10 and C11 due to cooking and cooling, C14 due to drying, C18) (UBA 2019, 2013c, d; Commins et al. 2011).

In the food $(\mathrm{C} 10)$, beverages $(\mathrm{C} 11)$ and printing and media $(\mathrm{C} 18)$ industries, companies cut inputs, when governments raise pollution taxes, resulting in efficiency gains and suggesting the factor endowment hypothesis. Confirming the factor endowment hypothesis, corporations in the textiles sector $(\mathrm{C} 13)$ purchase larger input amounts and enjoy productivity gains. Keeping input amounts constant, other production processes are adjusted in the leather (C15), chemicals (C20), rubber and plastics (C22), metal (C24), machinery (C28), motor vehicle (C29), furniture (C31), and other manufacturing (C32) industries. These findings support the factor endowment hypothesis. When raising pollution tax rates in the wearing apparel industry (C14), firms employ larger amounts of every input, favouring the Porter hypothesis. Plausibly, relevant industries benefit from efficiency gains, as they pollute water and air and rely extensively on chemicals next to being energy-intensive (C10, C11, C14, C15, C20, C24) and producing energy consuming products (C28, C29) (UBA 2019; Richter and Schiersch 2017; UBA 2013a, b, c).

Conversely, in the metal processing sector (C25), companies reduce all inputs when pollution tax rates rise, implying productivity losses and favouring the pollution haven hypothesis. Companies operating in the wood $(\mathrm{C} 16)$ and electrical equipment (C27) industries adjust aspects of production processes other than inputs, decreasing technical efficiency. Rising production costs, resulting from higher taxes, cannot be compensated by technological progress that fast (C16 and C25 are already obliged to filter emissions (UBA 2014, 2013d), but searching for environmentally friendly substitutes takes long) and, therefore, firms lose rents.

Concerning the spillovers, Franco and Marin (2017) find significantly positive effects of downstream total environmental tax rates and significantly negative ones of upstream total environmental tax rates on sector-level value added and productivity arguing that downstream taxes spur sellers to innovate, while upstream tax raises hamper innovation. Although energy taxes make up the largest share of total environmental taxes, my results partially confirm their conclusion. For instance, energy taxes can be shifted to customers more easily than other taxes (Commins et al. 2011). Hence, tax raises induce consumers to buy less and sellers, therefore, purchase less from their suppliers, reducing demand, but providing incentives to innovate and implying an insignificant effect of downstream taxation. Conversely, 
suppliers may shift rising taxes to customers who might not be able to sufficiently innovate or substitute inputs, implying efficiency losses to buyers and a negative effect of upstream taxes. Interpreted as elasticities, raising downstream or upstream energy tax rates by one percentage point results in changes of the dependent variables by -1.33 to $+0.48 \%$. Contrarily, the opposite holds for pollution tax rates. Higher upstream taxes might spur suppliers to innovate, as they cannot easily shift the tax, also benefiting their customers and resulting in a significantly positive effect of upstream taxation. As customers might face difficulties when shifting taxes to their customers, they may shift them to suppliers, implying a significantly negative impact of downstream taxes. When increasing downstream or upstream pollution tax rates by one per mill, dependent variables change by -6.19 to $+2.79 \%$.

Like Commins et al. (2011), average real wages significantly increase productivity, as more human capital allows to produce more efficiently, and decreases employment due to higher costs. Consequently, employment is substituted with material. If the variable rises by $1 \%$, dependent variables change by -0.16 to $+0.06 \%$. In comparison, import penetration significantly decreases employment due to the more intense competition from foreign countries. Consequently, productivity decreases, as demand for domestic products declines. An increase by one percentage point, reduces dependent variables by $0.03-0.21 \%$. As expected, the functional form of the relationship between domestic competition and productivity diplays the concave shape, as competition boosts productivity in a less competitive market, but reduces efficiency growth in highly competitive industries (Inui et al. 2012; Van Reenen 2011; Aghion et al. 2005).

\subsection{Discussion}

The overriding goal of green tax reforms is to design competitive, efficient and environmentally friendly markets. Nonetheless, green tax reforms, aiming to achieve productive and allocative efficiency, are a Herculean task due to the trade-off between productive efficiency and climate protection. This study sheds light on the impacts of environmental taxation and its spillovers on firm behaviour and performance, and highlights strong effects on productivity. In many industries, firms adjust production processes, suggesting that regulation induces innovation. Developing new technologies and innovating, however, takes more time in particular industries such that firms lose rents.

Concerning the magnitudes, effects of energy tax rates are not directly comparable with those by Commins et al. (2011). First, they only involve energy tax rates as the single variables of interest and exclude real material expenditures and tax spillovers. Second, they estimate elasticities, while I regress semi-elasticities. Third, production functions are estimated differently. Fourth, they introduce country-level control variables, while I employ nested country-year dummies. Fifth, I use fixed effects regressions considering endogeneity of environmental policy instead of employing first-differencing treating policy variables as exogenous. Nonetheless, I observe fewer significant effects on input amounts, but the results generally, as productivity responds positively to taxation in industries that are energy-intensive or 
polluting, produce energy consuming products or rely heavily on chemicals, while negative effects are observed in industries declining in Europe. Concerning energy tax rates, my results are in line with Fujii et al. (2016) who conclude that energy conservation laws raised productivity in the metals and machinery sectors. My results confirm those by Broberg et al. (2013) in the sense that the Porter hypothesis does not hold for European manufacturing sectors. Though Franco and Marin (2017) use total environmental tax rates and sector-level data, the results for energy taxation, making up the largest part of the former, partially agree.

However, one set of econometric issues results from employing deflated monetary output values instead of quantities. Potential differences in input prices across firms, originating from differences in the access to input markets or monopsonies, might cause 'input price biases' (negatively biased coefficients, upwards biased productivity). Like the literature, I implicitly assume that all firms of a given country face identical input prices. In case of input price differences, my estimates suffer from input price biases, because I rely on two deflated monetary inputs (De Loecker and Goldberg 2014).

Last, another set of econometric issues stems from using deflated monetary values of output instead of quantities, called 'omitted price variable bias'. Unfortunately, price indices are only available at industry-level, while firm-level or product-level price indices would be required. Applying industry-level price indices to firm-level operating revenues implies biased production function coefficients, if product- or firm-level prices deviate from the development of industry-level price indexes, which are captured by the error term. The direction of each coefficient's bias is not straightforward and can go in either direction (De Loecker and Goldberg (2014), De Loecker (2007b), Klette and Griliches (1996)). To solve this problem, in the spirit of Klette and Griliches (1996), De Loecker (2007b) proposes a framework, based on including industry-specific aggregate demand shifters, which, however, fails to correctly identify coefficients, because multiplying all asymmetrically biased input coefficients with a constant cannot yield unbiased coefficients (Ornaghi 2006).

\section{Conclusion}

I investigate the effects of environmental taxes on firm behaviour to provide policy lessons for designing green tax reforms. Therefore, in the first stage, Cobb-Douglas production functions are estimated with the algorithm by Ackerberg et al. (2015), using data on Central European manufacturing firms, from 2009 to 2017. In the second stage, I estimate the impacts of environmental taxation on productivity and firm behaviour with fixed effects models.

The results show that productivity significantly responds in many industries that are energy-intensive or polluting, produce energy consuming products, rely heavily on chemicals or are declining in Europe. In few industries, the pollution haven hypothesis holds, while other industries respond by substituting inputs with each other, purchasing larger input amounts or changing other processes, thereby decreasing productivity, as relocating to other countries is not easy. Downstream energy tax rates do not affect productivity, while upstream ones decrease technical efficiency. Downstream pollution taxation decreases productivity, whereas upstream taxation 
spurs technical efficiency. Policy makers should consider significantly negative impacts of environmental taxes and their spillovers on productivity. First, I suggest to implement green tax reforms raising environmental tax rates to spur innovation and, consequently, technical efficiency. Second, I recommend to complement them with the introduction of investment incentives, wage tax cuts or other compensations to bolster negative impacts on productivity, investment and employment.

\section{Appendix}

\section{The method by Ackerberg/Caves/Frazer}

When estimating production functions, much consideration needs to be given to identification problems. First, simultaneity biases arise because of endogeneous inputs, i.e. firms with positive productivity shocks demand larger input amounts. Second, attrition in the data causes identification problems, because firms with high productivity levels have higher probabilities to survive, while firms with low levels of productivity are more likely to exit the market (Olley and Pakes 1996).

Unlike Olley and Pakes (1996) and Levinsohn and Petrin (2003), Ackerberg et al. (2015) allow for a dynamic specification in the choice of labour by claiming that labour also depends on unobserved productivity. Hence, the coefficients of free variables (e.g. labour) cannot be correctly identified in the first stages of Olley and Pakes (1996) and Levinsohn and Petrin (2003). Instead, the coefficients are estimated in the second stage. To get the intuition, imagine a subperiod between periods $t-1$ and $t$. Firstly, the firm chooses the optimal amount of material. Secondly, the productivity shock occurs in the subperiod. Thirdly, the amount of labour is purchased. Now, labour is an element of the demand function for material in period $t$, which is still invertible as long as $m$ is strictly increasing in productivity.

In the first stage, I run

$$
y_{i, t}=\phi_{i, t}\left(l_{i, t}, k_{i, t}, m_{i, t}\right)+\psi_{i, t}
$$

to obtain estimates for the expected output $\hat{\phi}_{i, t}$ and the productivity shock $\hat{\psi}_{i, t}$. The expected output is

$$
\phi_{i, t}=\beta_{k} \cdot k_{i, t}+\beta_{l} \cdot l_{i, t}+\beta_{m} \cdot m_{i, t}+h_{t}^{-1}\left(m_{i, t}, k_{i, t}\right)
$$

with $h^{-1}(\cdot)$ being the inverted demand for material (proxy variable). Assuming that the demand for material is strictly monotonically increasing in productivity allows to invert the demand function to obtain productivity as a function of the proxy and state variables. Then, unobserved productivity $\omega$ is substituted with the inverted function, giving Eq. (5).

In the second stage, estimates for all production function coefficients $\beta=\left(\beta_{k}, \beta_{l}, \beta_{m}\right)$ are calculated by relying on the law of motion of productivity

$$
\omega_{i, t}=g_{t}\left(\omega_{i, t-1}\right)+\xi_{i, t}
$$


using Eq. (7).

$$
\omega_{i, t}(\beta)=\phi_{i, t}-\beta_{k} \cdot k_{i, t}-\beta_{l} \cdot l_{i, t}-\beta_{m} \cdot m_{i, t}
$$

Non-parametrically regressing $\omega(\beta)$ on its lag recovers the innovations to productivity $\xi$, required to form moment conditions, used to estimate the coefficients $\beta$ with GMM. To obtain the standard errors of $\beta$, I rely on cluster bootstrapping.

$$
\begin{aligned}
& E\left[\xi_{i, t} \cdot k_{i, t}\right]=0 \\
& E\left[\xi_{i, t} \cdot l_{i, t-1}\right]=0 \\
& E\left[\xi_{i, t} \cdot m_{i, t-1}\right]=0
\end{aligned}
$$

\begin{tabular}{|c|c|}
\hline Two-digit NACE industry & Name \\
\hline $\mathrm{C} 10$ & Food products \\
\hline $\mathrm{C} 11$ & Beverages \\
\hline $\mathrm{C} 12$ & Tobacco products \\
\hline $\mathrm{C} 13$ & Textiles \\
\hline $\mathrm{C} 14$ & Wearing apparel \\
\hline $\mathrm{C} 15$ & Leather and related products \\
\hline $\mathrm{C} 16$ & $\begin{array}{l}\text { Wood and products of wood and cork, except furniture; } \\
\text { articles of straw and plaiting materials }\end{array}$ \\
\hline $\mathrm{C} 17$ & Paper and pulp products \\
\hline $\mathrm{C} 18$ & Printing and reproduction of recorded media \\
\hline C19 & Coke and refined petroleum products \\
\hline $\mathrm{C} 20$ & Chemicals and chemical products \\
\hline $\mathrm{C} 21$ & Basic pharmaceutical products and preparations \\
\hline $\mathrm{C} 22$ & Rubber and plastics products \\
\hline $\mathrm{C} 23$ & Other non-metallic mineral products \\
\hline $\mathrm{C} 24$ & Basic metals \\
\hline $\mathrm{C} 25$ & Fabricated metal products, except machinery and equipment \\
\hline $\mathrm{C} 26$ & Computer, electronic and optical products \\
\hline $\mathrm{C} 27$ & Electrical equipment \\
\hline $\mathrm{C} 28$ & Machinery and equipment n.e.c. \\
\hline $\mathrm{C} 29$ & Motor vehicles, trailers and semi-trailers \\
\hline $\mathrm{C} 30$ & Other transport equipment \\
\hline $\mathrm{C} 31$ & Furniture \\
\hline $\mathrm{C} 32$ & Other manufacturing \\
\hline $\mathrm{C} 33$ & Repair and installation of machinery and equipment \\
\hline
\end{tabular}

\section{Industry codes}

See Table 3 .

Table 3 Two-digit NACE industry codes 


\section{Descriptives}

See Table 4.

Table 4 Descriptive statistics

\begin{tabular}{|c|c|c|c|c|}
\hline Variable & Unit & Mean (SD) & Min-Med-Max & $\mathrm{IQR}(\mathrm{CV})$ \\
\hline $\log (\mathrm{TFP})$ & & $4.4(2.1)$ & $-37.7<4.2<13.9$ & $1.9(0.5)$ \\
\hline $\begin{array}{l}\text { Real operating rev- } \\
\text { enues }\end{array}$ & Mill. Euro & $22.2(168.2)$ & $0<3.1<14,089.2$ & $8.9(7.6)$ \\
\hline $\begin{array}{l}\text { Real material expen- } \\
\text { ditures }\end{array}$ & Mill. Euro & $13.7(123.7)$ & $0<1.4<10179.1$ & $4.6(9)$ \\
\hline Real tangible assets & Mill. Euro & $9.3(1301.3)$ & $0<0.8<452,504.6$ & $2.7(140.1)$ \\
\hline Number employees & Integer & $127(334.8)$ & $1<38<15,000$ & $110(2.6)$ \\
\hline Real investment & Mill. Euro & $1(2028.4)$ & $\begin{array}{l}-452498.1<0.1< \\
452501\end{array}$ & $0.4(2029)$ \\
\hline Energy tax rate & Percentage point & $1.5(3.6)$ & $0<0.7<48.8$ & $0.8(2.5)$ \\
\hline $\begin{array}{l}\text { Energy tax rate down- } \\
\text { stream }\end{array}$ & Percentage point & $1.8(1.1)$ & $0<1.5<6.6$ & $1.4(0.6)$ \\
\hline $\begin{array}{l}\text { Energy tax rate } \\
\text { upstream }\end{array}$ & Percentage point & $3.2(1.6)$ & $0.6<2.8<13$ & $2(0.5)$ \\
\hline Pollution tax rate & Per Mill & $0.6(1.7)$ & $0<0.1<36.3$ & $0.3(2.9)$ \\
\hline $\begin{array}{l}\text { Pollution tax rate } \\
\text { downstream }\end{array}$ & Per Mill & $0.4(0.6)$ & $0<0.2<3.7$ & $0.5(1.3)$ \\
\hline $\begin{array}{l}\text { Pollution tax rate } \\
\text { upstream }\end{array}$ & Per Mill & $0.7(0.8)$ & $0<0.4<8.6$ & $0.7(1.1)$ \\
\hline Average real wage & Euro & $18,833.3(172,487.4)$ & $\begin{array}{l}0.3<142,65.5< \\
\quad 48415712\end{array}$ & $10,152.6(9.2)$ \\
\hline Import penetration & Percentage point & $44.7(15)$ & $0<43.2<90.8$ & $15.3(0.3)$ \\
\hline Inverted HHI & & $0.9(0.1)$ & $0<0.9<1$ & $0.1(0.2)$ \\
\hline
\end{tabular}

'Mean' denotes the average, 'SD' the standard deviation, 'Min' the minimum value, 'Med' the median,

'Max' the maximum value, 'IQR' the interquartile range and ' $\mathrm{CV}$ ' the coefficient of variation

\section{Estimates of the first stage}

See Tables 5-9.

Table 5 Results of production function estimation for Austria

\begin{tabular}{|c|c|c|c|c|c|c|c|}
\hline \multirow[t]{2}{*}{ Industry } & Labour & Capital & Material & $\begin{array}{l}\text { Number } \\
\text { observa- } \\
\text { tions }\end{array}$ & Number firms & $p$-Value CRS & Attrition \\
\hline & (1) & (2) & (3) & (4) & (5) & (6) & (7) \\
\hline \multirow{2}{*}{$\begin{array}{l}\mathrm{C} 10 \text { food } \\
\text { products }\end{array}$} & $0.361 * * *$ & $0.044 * *$ & $0.578 * * *$ & 367 & 97 & 0.57 & Yes \\
\hline & $(0.456)$ & $(0.018)$ & $(0.084)$ & & & & \\
\hline
\end{tabular}




\begin{tabular}{|c|c|c|c|c|c|c|c|}
\hline \multirow[t]{2}{*}{ Industry } & Labour & Capital & Material & $\begin{array}{l}\text { Number } \\
\text { observa- } \\
\text { tions }\end{array}$ & Number firms & $p$-Value CRS & Attrition \\
\hline & (1) & (2) & (3) & (4) & (5) & (6) & (7) \\
\hline \multirow[t]{2}{*}{ C11 beverages } & NA & NA & NA & 53 & 15 & NA & No \\
\hline & NA & NA & NA & & & & \\
\hline \multirow[t]{2}{*}{ C13 textiles } & $0.266 * * *$ & $0.061 * * *$ & $0.660 * * *$ & 91 & 24 & 0.09 & Yes \\
\hline & $(0.022)$ & $(0.018)$ & $(0.013)$ & & & & \\
\hline \multirow{2}{*}{$\begin{array}{l}\text { C14 wearing } \\
\text { apparel }\end{array}$} & NA & NA & NA & 26 & 10 & NA & No \\
\hline & NA & NA & NA & & & & \\
\hline \multirow[t]{2}{*}{ C15 leather } & NA & NA & NA & 27 & 6 & NA & No \\
\hline & NA & NA & NA & & & & \\
\hline \multirow{2}{*}{$\begin{array}{r}\mathrm{C} 16 \text { wood } \\
\text { products }\end{array}$} & $0.406^{* * *}$ & 0.086 & $0.513 * * *$ & 197 & 56 & 0.89 & No \\
\hline & $(0.028)$ & $(0.060)$ & $(0.105)$ & & & & \\
\hline \multirow{2}{*}{$\begin{array}{l}\text { C17 paper and } \\
\text { pulp products }\end{array}$} & 0.220 & 0.033 & 0.823 & 134 & 28 & 1.00 & No \\
\hline & $(0.272)$ & $(0.045)$ & (1.014) & & & & \\
\hline \multirow{2}{*}{$\begin{array}{l}\text { C18 printing } \\
\text { and recorded } \\
\text { media }\end{array}$} & 0.598 & $-0.090 * *$ & 0.557 & 98 & 25 & 1.00 & Yes \\
\hline & (1.269) & $(0.037)$ & $(1.086)$ & & & & \\
\hline \multirow{2}{*}{$\begin{array}{l}\mathrm{C} 20 \text { chemicals } \\
\text { and chemical } \\
\text { products }\end{array}$} & $0.444 * * *$ & $0.124 * *$ & 0.239 & 213 & 53 & 0.58 & Yes \\
\hline & $(0.128)$ & $(0.061)$ & $(0.205)$ & & & & \\
\hline \multirow{2}{*}{$\begin{array}{l}\mathrm{C} 21 \text { phar- } \\
\text { maceutical } \\
\text { products }\end{array}$} & $0.158 * * *$ & 0.046 & $0.812 * * *$ & 88 & 21 & 0.84 & Yes \\
\hline & $(0.017)$ & $(0.072)$ & $(0.031)$ & & & & \\
\hline \multirow{2}{*}{$\begin{array}{l}\mathrm{C} 22 \text { rubber } \\
\text { and plastics } \\
\text { products }\end{array}$} & $0.216^{* * * *}$ & $0.054 * * *$ & $0.706^{* * *}$ & 209 & 57 & 0.00 & Yes \\
\hline & $(0.000)$ & $(0.000)$ & $(0.000)$ & & & & \\
\hline \multirow{2}{*}{$\begin{array}{l}\text { C23 other } \\
\text { non-metallic } \\
\text { mineral } \\
\text { products }\end{array}$} & $0.576^{* * *} *$ & $0.173^{* * *}$ & $1.541 * * *$ & 237 & 67 & 0.00 & Yes \\
\hline & $(0.097)$ & $(0.034)$ & $(0.260)$ & & & & \\
\hline \multirow{2}{*}{$\begin{array}{l}\text { C24 basic } \\
\text { metals }\end{array}$} & $0.485^{* * * *}$ & $-0.051 * * *$ & $0.664 * * *$ & 273 & 58 & 0.00 & Yes \\
\hline & $(0.000)$ & $(0.000)$ & $(0.000)$ & & & & \\
\hline
\end{tabular}




\begin{tabular}{llllll}
\hline Industry & Labour & Capital & Material & Number & Number firms \\
-Value CRS Attrition
\end{tabular}
observa-

(1)

(2)

(3)

(4)

(5)

(6)

(7)

\begin{tabular}{|c|c|c|c|c|c|c|c|}
\hline \multirow{2}{*}{$\begin{array}{l}\text { C25 fabricated } \\
\text { metal prod- } \\
\text { ucts }\end{array}$} & $0.566^{* * * *}$ & 0.001 & $0.452 * * *$ & 451 & 137 & 0.92 & Yes \\
\hline & $(0.010)$ & (0.019) & $(0.080)$ & & & & \\
\hline \multirow{2}{*}{$\begin{array}{l}\text { C26 computer, } \\
\text { electronic, } \\
\text { optical prod- } \\
\text { ucts }\end{array}$} & 0.697 & 0.083 & 0.068 & 230 & 64 & 0.82 & Yes \\
\hline & $(0.563)$ & $(0.076)$ & $(0.053)$ & & & & \\
\hline \multirow{2}{*}{$\begin{array}{l}\text { C27 electrical } \\
\text { equipment }\end{array}$} & $0.204 * * *$ & $0.057 * *$ & $0.682 * * *$ & 172 & 46 & 0.00 & Yes \\
\hline & $(0.008)$ & $(0.027)$ & $(0.018)$ & & & & \\
\hline \multirow[t]{2}{*}{ C28 machinery } & $0.388 * * *$ & -0.034 & $0.625 * * *$ & 548 & 145 & 0.84 & Yes \\
\hline & $(0.058)$ & $(0.055)$ & $(0.025)$ & & & & \\
\hline \multirow{2}{*}{$\begin{array}{l}\text { C29 motor } \\
\text { vehicles, } \\
\text { trailers, semi- } \\
\text { trailers }\end{array}$} & 0.211 & 0.055 & 0.719 & 148 & 37 & 1.00 & Yes \\
\hline & $(0.184)$ & $(0.048)$ & $(0.629)$ & & & & \\
\hline \multirow{2}{*}{$\begin{array}{l}\text { C30 other } \\
\text { transport } \\
\text { equipment }\end{array}$} & NA & NA & NA & 33 & 9 & NA & No \\
\hline & NA & NA & NA & & & & \\
\hline \multirow[t]{2}{*}{ C31 furniture } & $0.136^{* * *}$ & $0.043^{*}$ & $0.737 * * *$ & 61 & 20 & 0.45 & Yes \\
\hline & $(0.019)$ & $(0.023)$ & $(0.087)$ & & & & \\
\hline \multirow{2}{*}{$\begin{array}{l}\text { C32 other } \\
\text { manufactur- } \\
\text { ing }\end{array}$} & $0.597 * * *$ & 0.038 & $0.550 * * *$ & 70 & 24 & 0.00 & Yes \\
\hline & $(0.018)$ & $(0.039)$ & $(0.016)$ & & & & \\
\hline \multirow{2}{*}{$\begin{array}{l}\text { C33 repair, } \\
\text { installation }\end{array}$} & $0.879 * * *$ & 0.055 & $0.225 * * *$ & 63 & 19 & 0.02 & No \\
\hline & $(0.068)$ & $(0.045)$ & $(0.035)$ & & & & \\
\hline
\end{tabular}

All elasticities are cluster bootstrapped at the firm-level. Firms with negative or zero output and input amounts are automatically dropped by using logged variables.

${ }^{*} p<0.1 ; * * p<0.05 ; * * * p<0.01$ 
Table 6 Results of production function estimation for Czech Republic

\begin{tabular}{|c|c|c|c|c|c|c|c|}
\hline \multirow[t]{2}{*}{ Industry } & Labour & Capital & Material & $\begin{array}{l}\text { Number } \\
\text { observa- } \\
\text { tions }\end{array}$ & Number firms & $p$-Value CRS & Attrition \\
\hline & (1) & (2) & (3) & (4) & (5) & (6) & (7) \\
\hline $\begin{array}{l}\text { C10 food prod- } \\
\text { ucts }\end{array}$ & $\begin{array}{l}0.145^{* * * *} \\
(0.004)\end{array}$ & $\begin{array}{l}0.101 * * * \\
(0.024)\end{array}$ & $\begin{array}{l}0.768 * * * \\
(0.013)\end{array}$ & 4859 & 719 & 0.08 & Yes \\
\hline $\mathrm{C} 11$ beverages & $\begin{array}{l}0.160 * * * \\
(0.021)\end{array}$ & $\begin{array}{l}0.113 \\
(0.072)\end{array}$ & $\begin{array}{l}0.827 * * * \\
(0.012)\end{array}$ & 886 & 127 & 0.01 & Yes \\
\hline C13 textiles & $\begin{array}{l}0.319^{*} \\
(0.169)\end{array}$ & $\begin{array}{l}0.111^{*} \\
(0.059)\end{array}$ & $\begin{array}{l}0.551^{*} \\
(0.293)\end{array}$ & 1238 & 181 & 1.00 & Yes \\
\hline $\begin{array}{l}\text { C14 wearing } \\
\text { apparel }\end{array}$ & $\begin{array}{l}0.312 * * * \\
(0.007)\end{array}$ & $\begin{array}{l}0.055^{* * * *} \\
(0.018)\end{array}$ & $\begin{array}{l}0.611 * * * \\
(0.010)\end{array}$ & 814 & 130 & 0.00 & Yes \\
\hline C15 leather & $\begin{array}{l}0.435 * * * \\
(0.032)\end{array}$ & $\begin{array}{l}0.087 * \\
(0.045)\end{array}$ & $\begin{array}{l}0.499 * * * \\
(0.034)\end{array}$ & 267 & 42 & 0.76 & Yes \\
\hline $\begin{array}{r}\text { C16 wood } \\
\text { products }\end{array}$ & $\begin{array}{l}0.238 * * * \\
(0.009)\end{array}$ & $\begin{array}{l}0.074 * * \\
(0.036)\end{array}$ & $\begin{array}{l}0.668 * * * \\
(0.008)\end{array}$ & 2387 & 352 & 0.26 & Yes \\
\hline $\begin{array}{l}\text { C17 paper and } \\
\text { pulp products }\end{array}$ & $\begin{array}{l}0.244 * * * \\
(0.000)\end{array}$ & $\begin{array}{l}0.052 * * * \\
(0.000)\end{array}$ & $\begin{array}{l}0.746^{* * * *} \\
(0.000)\end{array}$ & 1159 & 164 & 0.00 & Yes \\
\hline $\begin{array}{l}\text { C18 printing } \\
\text { and recorded } \\
\text { media }\end{array}$ & $(0.011)$ & $(0.026)$ & $(0.014)$ & 1323 & 191 & 0.00 & Yes \\
\hline $\begin{array}{l}\mathrm{C} 20 \text { chemicals } \\
\text { and chemical } \\
\text { products }\end{array}$ & $(0.012)$ & $(0.061)$ & $(0.017)$ & 1666 & 216 & 0.21 & Yes \\
\hline $\begin{array}{l}\text { C21 pharmaceu- } \\
\text { tical products }\end{array}$ & $\begin{array}{l}0.160 * * * \\
(0.055)\end{array}$ & $\begin{array}{l}0.115^{* *} \\
(0.046)\end{array}$ & $\begin{array}{l}0.683 * * * \\
(0.117)\end{array}$ & 347 & 44 & 0.28 & No \\
\hline $\begin{array}{l}\text { C22 rubber } \\
\text { and plastics } \\
\text { products }\end{array}$ & $(0.000)$ & $(0.000)$ & $(0.000)$ & 4933 & 669 & 0.00 & Yes \\
\hline $\begin{array}{l}\text { C23 other non- } \\
\text { metallic min- } \\
\text { eral products }\end{array}$ & $(0.000)$ & $(0.000)$ & $(0.000)$ & 2572 & 355 & 0.00 & Yes \\
\hline $\begin{array}{l}\mathrm{C} 24 \text { basic met- } \\
\text { als }\end{array}$ & $\begin{array}{l}0.255^{* * * *} \\
(0.018)\end{array}$ & $\begin{array}{l}0.029 \\
(0.049)\end{array}$ & $\begin{array}{l}0.721 * * * \\
(0.010)\end{array}$ & 1268 & 177 & 0.86 & Yes \\
\hline $\begin{array}{l}\text { C25 fabricated } \\
\text { metal products }\end{array}$ & $\begin{array}{l}0.295^{* * * *} \\
(0.003)\end{array}$ & $\begin{array}{l}0.083 * * * \\
(0.016)\end{array}$ & $\begin{array}{l}0.601 * * * \\
(0.005)\end{array}$ & 11,977 & 1751 & 0.01 & Yes \\
\hline
\end{tabular}




\begin{tabular}{|c|c|c|c|c|c|c|c|}
\hline Industry & Labour & Capital & Material & $\begin{array}{l}\text { Number } \\
\text { observa- } \\
\text { tions } \\
\text { (4) }\end{array}$ & Number firms & $p$-Value CRS & Attrition \\
\hline \multirow{2}{*}{$\begin{array}{l}\text { C26 computer, } \\
\text { electronic, } \\
\text { optical prod- } \\
\text { ucts }\end{array}$} & $0.338 * * *$ & $0.054 * * *$ & $0.634 * * * *$ & 1741 & 236 & 0.01 & Yes \\
\hline & (0.004) & $(0.016)$ & (0.005) & & & & \\
\hline \multirow{2}{*}{$\begin{array}{l}\text { C27 electrical } \\
\text { equipment }\end{array}$} & $0.357 * * *$ & $0.055^{* * * *}$ & $0.572 * * * *$ & 3645 & 500 & 0.00 & Yes \\
\hline & $(0.000)$ & $(0.000)$ & $(0.000)$ & & & & \\
\hline \multirow[t]{2}{*}{ C28 machinery } & $0.284 * * *$ & $0.052 * * *$ & $0.663 * * *$ & 7172 & 960 & 0.00 & Yes \\
\hline & $(0.000)$ & $(0.000)$ & $(0.000)$ & & & & \\
\hline \multirow{2}{*}{$\begin{array}{l}\text { C29 motor vehi- } \\
\text { cles, trailers, } \\
\text { semi-trailers }\end{array}$} & $0.364 * * *$ & 0.020 & $0.659 * * *$ & 2701 & 363 & 0.00 & Yes \\
\hline & $(0.005)$ & (0.018) & $(0.003)$ & & & & \\
\hline \multirow{2}{*}{$\begin{array}{l}\text { C30 other } \\
\text { transport } \\
\text { equipment }\end{array}$} & $0.259 * * *$ & -0.013 & $0.740 * * *$ & 728 & 97 & 0.50 & Yes \\
\hline & $(0.008)$ & $(0.032)$ & $(0.012)$ & & & & \\
\hline \multirow[t]{2}{*}{ C31 furniture } & $0.197 * * *$ & $0.033^{*}$ & $0.756^{* * * *}$ & 1554 & 228 & 0.38 & Yes \\
\hline & (0.009) & $(0.017)$ & $(0.007)$ & & & & \\
\hline \multirow{2}{*}{$\begin{array}{l}\text { C32 other manu- } \\
\text { facturing }\end{array}$} & $0.352 * * *$ & 0.023 & $0.614 * * *$ & 1511 & 228 & 0.28 & Yes \\
\hline & $(0.005)$ & $(0.018)$ & (0.002) & & & & \\
\hline \multirow{2}{*}{$\begin{array}{l}\text { C33 repair, } \\
\text { installation }\end{array}$} & $0.421 * * *$ & 0.029 & $0.546^{* * * *}$ & 3388 & 507 & 0.70 & Yes \\
\hline & $(0.013)$ & $(0.024)$ & (0.004) & & & & \\
\hline
\end{tabular}

All elasticities are cluster bootstrapped at the firm-level. Firms with negative or zero output and input amounts are automatically dropped by using logged variables.

${ }^{*} p<0.1 ;{ }^{* *} p<0.05 ;{ }^{* * *} p<0.01$

Table 7 Results of production function estimation for Hungary

\begin{tabular}{|c|c|c|c|c|c|c|c|}
\hline Industry & $\begin{array}{l}\text { Labour } \\
\text { (1) }\end{array}$ & (2) & $\begin{array}{l}\text { Material } \\
\text { (3) }\end{array}$ & $\begin{array}{l}\text { Number } \\
\text { observa- } \\
\text { tions } \\
(4)\end{array}$ & Number firms & $p$-Value CRS & Attrition \\
\hline $\begin{array}{l}\text { C10 food prod- } \\
\text { ucts }\end{array}$ & $\begin{array}{c}0.283 * * * \\
(0.011)\end{array}$ & $\begin{array}{l}0.180 * * * \\
(0.036)\end{array}$ & $\begin{array}{l}0.504 * * * \\
(0.014)\end{array}$ & 2801 & 428 & 0.08 & Yes \\
\hline $\mathrm{C} 11$ beverages & $\begin{array}{l}0.504 \\
(0.442)\end{array}$ & $\begin{array}{l}0.054 \\
(0.046)\end{array}$ & $\begin{array}{l}0.568 \\
(0.503)\end{array}$ & 580 & 90 & 0.89 & Yes \\
\hline C13 textiles & $\begin{array}{l}0.352 * * * \\
(0.134)\end{array}$ & $\begin{array}{l}0.149 * * \\
(0.072)\end{array}$ & $\begin{array}{l}0.502^{* * * *} \\
(0.080)\end{array}$ & 315 & 55 & 1.00 & Yes \\
\hline
\end{tabular}




\begin{tabular}{|c|c|c|c|c|c|c|c|}
\hline Industry & (1) & (2) & (3) & $\begin{array}{l}\text { Number } \\
\text { observa- } \\
\text { tions } \\
(4)\end{array}$ & Number firms & $p$-Value CRS & Attrition \\
\hline $\begin{array}{l}\text { C14 wearing } \\
\text { apparel }\end{array}$ & $\begin{array}{l}0.443 * * * \\
(0.019)\end{array}$ & $\begin{array}{l}0.035 \\
(0.030)\end{array}$ & $\begin{array}{l}0.340 * * * \\
(0.016)\end{array}$ & 312 & 48 & 0.00 & Yes \\
\hline C15 leather & $\begin{array}{l}0.299 * * * \\
(0.019)\end{array}$ & $\begin{array}{l}0.169^{* * *} \\
(0.060)\end{array}$ & $\begin{array}{l}0.490 * * * \\
(0.030)\end{array}$ & 166 & 23 & 0.00 & Yes \\
\hline $\begin{array}{r}\text { C16 wood } \\
\text { products }\end{array}$ & $\begin{array}{l}0.291 * * * \\
(0.074)\end{array}$ & $\begin{array}{l}-0.076 \\
(0.092)\end{array}$ & $\begin{array}{l}0.720 * * * \\
(0.022)\end{array}$ & 425 & 73 & 0.05 & Yes \\
\hline $\begin{array}{l}\mathrm{C} 17 \text { paper and } \\
\text { pulp products }\end{array}$ & $\begin{array}{l}0.338 * * * \\
(0.054)\end{array}$ & $\begin{array}{l}0.290 * * * \\
(0.058)\end{array}$ & $\begin{array}{l}0.310 * * * \\
(0.027)\end{array}$ & 438 & 63 & 0.20 & Yes \\
\hline $\begin{array}{l}\text { C18 printing } \\
\text { and recorded } \\
\text { media }\end{array}$ & $(0.098)$ & $(0.052)$ & $(0.134)$ & 399 & 65 & 0.00 & Yes \\
\hline $\begin{array}{l}\mathrm{C} 20 \text { chemicals } \\
\text { and chemical } \\
\text { products }\end{array}$ & $(0.037)$ & (0.103) & $(0.063)$ & 619 & 90 & 0.27 & Yes \\
\hline $\begin{array}{l}\text { C21 pharmaceu- } \\
\text { tical products }\end{array}$ & $\begin{array}{l}0.253 * * * \\
(0.073)\end{array}$ & $\begin{array}{l}0.030 \\
(0.026)\end{array}$ & $\begin{array}{l}0.685^{* * * *} \\
(0.206)\end{array}$ & 238 & 32 & 0.92 & No \\
\hline $\begin{array}{l}\mathrm{C} 22 \text { rubber } \\
\text { and plastics } \\
\text { products }\end{array}$ & $(0.012)$ & $(0.060)$ & $\begin{array}{l}0.530 * * * \\
(0.031)\end{array}$ & 1579 & 227 & 0.82 & Yes \\
\hline $\begin{array}{l}\mathrm{C} 23 \text { other non- } \\
\text { metallic min- } \\
\text { eral products }\end{array}$ & $(0.116)$ & $(0.075)$ & $\begin{array}{l}0.500 * * * \\
(0.193)\end{array}$ & 921 & 123 & 1.00 & Yes \\
\hline $\mathrm{C} 24$ basic metals & $\begin{array}{l}0.386 \\
(0.279)\end{array}$ & $\begin{array}{l}0.197^{*} \\
(0.105)\end{array}$ & $\begin{array}{l}0.388^{* *} \\
(0.169)\end{array}$ & 394 & 54 & 1.00 & Yes \\
\hline $\begin{array}{l}\text { C25 fabricated } \\
\text { metal products }\end{array}$ & $\begin{array}{l}0.508 * * * \\
(0.000)\end{array}$ & $\begin{array}{l}0.027 * * * \\
(0.000)\end{array}$ & $\begin{array}{l}0.417 * * * \\
(0.000)\end{array}$ & 3191 & 474 & 0.00 & Yes \\
\hline $\begin{array}{l}\text { C26 computer, } \\
\text { electronic, } \\
\text { optical prod- } \\
\text { ucts }\end{array}$ & $(0.020)$ & $(0.007)$ & $(0.013)$ & 879 & 115 & 0.12 & Yes \\
\hline $\begin{array}{l}\text { C27 electrical } \\
\text { equipment }\end{array}$ & $\begin{array}{l}0.325^{* * * *} \\
(0.018)\end{array}$ & $\begin{array}{l}0.094 * * \\
(0.047)\end{array}$ & $\begin{array}{l}0.571 * * * \\
(0.088)\end{array}$ & 775 & 105 & 0.92 & Yes \\
\hline C28 machinery & $\begin{array}{l}0.380^{* * * *} \\
(0.005)\end{array}$ & $\begin{array}{l}0.073 * * \\
(0.035)\end{array}$ & $\begin{array}{l}0.511 * * * \\
(0.011)\end{array}$ & 1642 & 230 & 0.06 & Yes \\
\hline
\end{tabular}




\begin{tabular}{|c|c|c|c|c|c|c|c|}
\hline Industry & (1) & (2) & (3) & $\begin{array}{l}\text { Number } \\
\text { observa- } \\
\text { tions } \\
\text { (4) }\end{array}$ & Number firms & $p$-Value CRS & Attrition \\
\hline $\begin{array}{l}\text { C29 motor vehi- } \\
\text { cles, trailers, } \\
\text { semi-trailers }\end{array}$ & $(0.003)$ & $(0.016)$ & $(0.021)$ & 1029 & 136 & 0.00 & Yes \\
\hline $\begin{array}{l}\text { C30 other } \\
\text { transport } \\
\text { equipment }\end{array}$ & $(0.025)$ & $(0.032)$ & $(0.046)$ & 147 & 20 & 1.00 & No \\
\hline C31 furniture & $\begin{array}{l}0.526 \\
(0.333)\end{array}$ & $\begin{array}{l}0.136^{*} \\
(0.081)\end{array}$ & $\begin{array}{l}0.292^{*} \\
(0.168)\end{array}$ & 380 & 55 & 0.92 & Yes \\
\hline $\begin{array}{l}\text { C32 other manu- } \\
\text { facturing }\end{array}$ & $\begin{array}{l}0.353^{* * *} \\
(0.039)\end{array}$ & $\begin{array}{l}0.092 * * * \\
(0.023)\end{array}$ & $\begin{array}{l}0.497 * * * \\
(0.013)\end{array}$ & 431 & 70 & 0.04 & Yes \\
\hline $\begin{array}{l}\text { C33 repair, } \\
\text { installation }\end{array}$ & $\begin{array}{l}0.460 \\
(0.326)\end{array}$ & $\begin{array}{l}0.044 \\
(0.105)\end{array}$ & $\begin{array}{l}0.706^{* *} \\
(0.333)\end{array}$ & 336 & 57 & 0.71 & Yes \\
\hline
\end{tabular}

All elasticities are cluster bootstrapped at the firm-level. Firms with negative or zero output and input amounts are automatically dropped by using logged variables.

${ }^{*} p<0.1 ;{ }^{* *} p<0.05 ;{ }^{* * *} p<0.01$

Table 8 Results of production function estimation for Slovakia

\begin{tabular}{|c|c|c|c|c|c|c|c|}
\hline Industry & (1) & (2) & (3) & $\begin{array}{l}\text { Number } \\
\text { observa- } \\
\text { tions } \\
(4)\end{array}$ & Number firms & $p$-Value CRS & Attrition \\
\hline $\begin{array}{l}\text { C10 food prod- } \\
\text { ucts }\end{array}$ & $\begin{array}{l}0.146 * * * \\
(0.006)\end{array}$ & $\begin{array}{l}0.038 * * \\
(0.019)\end{array}$ & $\begin{array}{l}0.764 * * * \\
(0.010)\end{array}$ & 2485 & 399 & 0.00 & Yes \\
\hline $\mathrm{C} 11$ beverages & $\begin{array}{l}0.147 * * * \\
(0.041)\end{array}$ & $\begin{array}{l}0.122^{* * *} \\
(0.033)\end{array}$ & $\begin{array}{l}0.796^{* * * *} \\
(0.042)\end{array}$ & 520 & 77 & 0.00 & Yes \\
\hline C13 textiles & $\begin{array}{l}0.288 * * * \\
(0.023)\end{array}$ & $\begin{array}{l}0.099 * * * \\
(0.029)\end{array}$ & $\begin{array}{l}0.510^{* * * *} \\
(0.045)\end{array}$ & 510 & 81 & 0.00 & Yes \\
\hline $\begin{array}{l}\text { C14 wearing } \\
\text { apparel }\end{array}$ & $\begin{array}{l}0.387 * * * \\
(0.012)\end{array}$ & $\begin{array}{l}0.047^{*} \\
(0.028)\end{array}$ & $\begin{array}{l}0.474 * * * \\
(0.016)\end{array}$ & 895 & 148 & 0.00 & Yes \\
\hline C15 leather & $\begin{array}{l}0.447 * * * \\
(0.108)\end{array}$ & $\begin{array}{l}0.059 \\
(0.062)\end{array}$ & $\begin{array}{l}0.476^{* * * *} \\
(0.068)\end{array}$ & 363 & 58 & 0.68 & Yes \\
\hline $\begin{array}{r}\text { C16 wood } \\
\text { products }\end{array}$ & $\begin{array}{l}0.101 * * * \\
(0.020)\end{array}$ & $\begin{array}{l}0.097 * * \\
(0.040)\end{array}$ & $\begin{array}{l}0.678 * * * \\
(0.017)\end{array}$ & 1757 & 281 & 0.00 & Yes \\
\hline $\begin{array}{l}\text { C17 paper and } \\
\text { pulp products }\end{array}$ & $\begin{array}{l}0.132 * * * \\
(0.048)\end{array}$ & $\begin{array}{l}0.149 * * * \\
(0.047)\end{array}$ & $\begin{array}{l}0.801 * * * \\
(0.012)\end{array}$ & 405 & 58 & 0.03 & Yes \\
\hline
\end{tabular}




\begin{tabular}{|c|c|c|c|c|c|c|c|}
\hline Industry & (1) & (2) & (3) & $\begin{array}{l}\text { Number } \\
\text { observa- } \\
\text { tions } \\
(4)\end{array}$ & Number firms & $p$-Value CRS & Attrition \\
\hline $\begin{array}{l}\text { C18 printing } \\
\text { and recorded } \\
\text { media }\end{array}$ & $(0.012)$ & $(0.025)$ & $(0.016)$ & 555 & 80 & 0.00 & No \\
\hline $\begin{array}{l}\mathrm{C} 20 \text { chemicals } \\
\text { and chemical } \\
\text { products }\end{array}$ & $(0.150)$ & $(0.075)$ & $(0.484)$ & 462 & 75 & 0.92 & No \\
\hline $\begin{array}{l}\mathrm{C} 21 \text { pharmaceu- } \\
\text { tical products }\end{array}$ & NA & $\begin{array}{l}\text { NA } \\
\text { NA }\end{array}$ & $\begin{array}{l}\text { NA } \\
\text { NA }\end{array}$ & 98 & 13 & NA & No \\
\hline $\begin{array}{l}\mathrm{C} 22 \text { rubber } \\
\text { and plastics } \\
\text { products }\end{array}$ & $(0.012)$ & $(0.016)$ & $(0.006)$ & 2050 & 298 & 0.00 & Yes \\
\hline $\begin{array}{l}\mathrm{C} 23 \text { other non- } \\
\text { metallic min- } \\
\text { eral products }\end{array}$ & $(0.010)$ & $(0.037)$ & $(0.020)$ & 1156 & 171 & 0.00 & Yes \\
\hline $\begin{array}{l}\text { C24 basic met- } \\
\text { als }\end{array}$ & $\begin{array}{l}0.139 * * * \\
(0.032)\end{array}$ & $\begin{array}{l}0.038 \\
(0.057)\end{array}$ & $\begin{array}{l}0.763 * * * \\
(0.023)\end{array}$ & 437 & 61 & 0.00 & Yes \\
\hline $\begin{array}{l}\mathrm{C} 25 \text { fabricated } \\
\text { metal products }\end{array}$ & $\begin{array}{l}0.209 * * * \\
(0.009)\end{array}$ & $\begin{array}{l}0.000 \\
(0.012)\end{array}$ & $\begin{array}{l}0.575^{* * * *} \\
(0.011)\end{array}$ & 5764 & 911 & 0.00 & Yes \\
\hline $\begin{array}{l}\text { C26 computer, } \\
\text { electronic, } \\
\text { optical prod- } \\
\text { ucts }\end{array}$ & $(0.046)$ & $(0.054)$ & $(0.047)$ & 678 & 107 & 0.30 & Yes \\
\hline $\begin{array}{l}\text { C27 electrical } \\
\text { equipment }\end{array}$ & $\begin{array}{l}0.323 * * * \\
(0.017)\end{array}$ & $\begin{array}{l}0.056^{* * *} \\
(0.018)\end{array}$ & $\begin{array}{l}0.557 * * * \\
(0.013)\end{array}$ & 1227 & 177 & 0.04 & Yes \\
\hline C28 machinery & $\begin{array}{l}0.221 * * * \\
(0.006)\end{array}$ & $\begin{array}{l}0.077 * * * \\
(0.020)\end{array}$ & $\begin{array}{l}0.648^{* * * *} \\
(0.009)\end{array}$ & 2081 & 306 & 0.00 & Yes \\
\hline $\begin{array}{l}\text { C29 motor vehi- } \\
\text { cles, trailers, } \\
\text { semi-trailers }\end{array}$ & $(0.021)$ & $(0.032)$ & $\begin{array}{l}0.625^{* * *} \\
(0.017)\end{array}$ & 899 & 139 & 0.63 & Yes \\
\hline $\begin{array}{l}\text { C30 other } \\
\text { transport } \\
\text { equipment }\end{array}$ & $(0.119)$ & $(0.061)$ & $\begin{array}{l}0.694 * * * \\
(0.283)\end{array}$ & 164 & 23 & 1.00 & No \\
\hline C31 furniture & $\begin{array}{l}0.158^{* * *} \\
(0.011)\end{array}$ & $\begin{array}{l}0.058^{* *} \\
(0.025)\end{array}$ & $\begin{array}{l}0.691 * * * \\
(0.012)\end{array}$ & 914 & 135 & 0.00 & Yes \\
\hline
\end{tabular}




\begin{tabular}{|c|c|c|c|c|c|c|c|}
\hline \multirow[t]{2}{*}{ Industry } & Labour & Capital & Material & $\begin{array}{l}\text { Number } \\
\text { observa- } \\
\text { tions }\end{array}$ & Number firms & $p$-Value CRS & Attrition \\
\hline & (1) & (2) & (3) & (4) & (5) & (6) & (7) \\
\hline \multirow{2}{*}{$\begin{array}{l}\text { C32 other manu- } \\
\text { facturing }\end{array}$} & $0.251 * * *$ & 0.063 & $0.651 * * *$ & 446 & 67 & 0.52 & Yes \\
\hline & $(0.028)$ & $(0.070)$ & $(0.023)$ & & & & \\
\hline \multirow{2}{*}{$\begin{array}{l}\text { C33 repair, } \\
\text { installation }\end{array}$} & $0.361 * * *$ & 0.002 & $0.534 * * *$ & 1439 & 206 & 0.00 & Yes \\
\hline & $(0.014)$ & $(0.022)$ & $(0.008)$ & & & & \\
\hline
\end{tabular}

All elasticities are cluster bootstrapped at the firm-level. Firms with negative or zero output and input amounts are automatically dropped by using logged variables.

${ }^{*} p<0.1 ;{ }^{* *} p<0.05 ;{ }^{* * *} p<0.01$

Table 9 Results of production function estimation for Slovenia

\begin{tabular}{|c|c|c|c|c|c|c|c|}
\hline Industry & (1) & (2) & (3) & $\begin{array}{l}\text { Number } \\
\text { observa- } \\
\text { tions } \\
\text { (4) }\end{array}$ & Number firms & $p$-value CRS & Attrition \\
\hline $\begin{array}{l}\text { C10 food prod- } \\
\text { ucts }\end{array}$ & $\begin{array}{l}0.294 * * * \\
(0.012)\end{array}$ & $\begin{array}{l}0.026 \\
(0.022)\end{array}$ & $\begin{array}{l}0.679 * * * \\
(0.011)\end{array}$ & 1062 & 148 & 1.00 & Yes \\
\hline $\mathrm{C} 11$ beverages & $\begin{array}{l}0.264 * * * \\
(0.009)\end{array}$ & $\begin{array}{l}0.104 * * * \\
(0.035)\end{array}$ & $\begin{array}{l}0.709 * * * \\
(0.055)\end{array}$ & 120 & 16 & 0.35 & No \\
\hline C13 textiles & $\begin{array}{l}0.223 * * * \\
(0.033)\end{array}$ & $\begin{array}{l}0.240 * * \\
(0.118)\end{array}$ & $\begin{array}{l}0.452 * * * \\
(0.060)\end{array}$ & 336 & 43 & 0.15 & No \\
\hline $\begin{array}{l}\text { C14 wearing } \\
\text { apparel }\end{array}$ & $\begin{array}{l}2.434 * * * \\
(0.236)\end{array}$ & $\begin{array}{l}0.281 * * * \\
(0.040)\end{array}$ & $\begin{array}{l}2.127 * * * \\
(0.202)\end{array}$ & 211 & 28 & 0.00 & Yes \\
\hline C15 leather & $\begin{array}{l}0.265 * * * \\
(0.067)\end{array}$ & $\begin{array}{l}0.019 \\
(0.028)\end{array}$ & $\begin{array}{l}0.554 * * * \\
(0.082)\end{array}$ & 130 & 15 & 0.00 & Yes \\
\hline $\begin{array}{r}\text { C16 wood } \\
\text { products }\end{array}$ & $\begin{array}{l}0.374 \\
(0.239)\end{array}$ & $\begin{array}{l}0.021 \\
(0.049)\end{array}$ & $\begin{array}{l}0.494 \\
(0.306)\end{array}$ & 1138 & 156 & 0.84 & Yes \\
\hline $\begin{array}{l}\text { C17 paper and } \\
\text { pulp products }\end{array}$ & $\begin{array}{l}0.199 * \\
(0.112)\end{array}$ & $\begin{array}{l}0.091 \\
(0.058)\end{array}$ & $\begin{array}{l}0.683^{*} \\
(0.390)\end{array}$ & 308 & 43 & 1.00 & Yes \\
\hline $\begin{array}{l}\mathrm{C} 18 \text { printing and } \\
\text { recorded media }\end{array}$ & $\begin{array}{l}0.317 * * * \\
(0.019)\end{array}$ & $\begin{array}{l}0.087 \\
(0.062)\end{array}$ & $\begin{array}{l}0.421 * * * \\
(0.065)\end{array}$ & 508 & 67 & 0.00 & Yes \\
\hline $\begin{array}{l}\text { C20 chemicals } \\
\text { and chemical } \\
\text { products }\end{array}$ & $(0.011)$ & $(0.026)$ & $(0.014)$ & 504 & 61 & 0.59 & No \\
\hline $\begin{array}{l}\text { C21 pharmaceu- } \\
\text { tical products }\end{array}$ & $\begin{array}{l}\mathrm{NA} \\
\mathrm{NA}\end{array}$ & NA & $\begin{array}{l}\text { NA } \\
\text { NA }\end{array}$ & 50 & 6 & NA & No \\
\hline
\end{tabular}




\begin{tabular}{|c|c|c|c|c|c|c|c|}
\hline Industry & (1) & (2) & (3) & $\begin{array}{l}\text { Number } \\
\text { observa- } \\
\text { tions } \\
\text { (4) }\end{array}$ & Number firms & $p$-value CRS & Attrition \\
\hline $\begin{array}{l}\mathrm{C} 22 \text { rubber } \\
\text { and plastics } \\
\text { products }\end{array}$ & $(0.010)$ & $(0.007)$ & $(0.018)$ & 1628 & 219 & 0.24 & Yes \\
\hline $\begin{array}{l}\text { C23 other non- } \\
\text { metallic min- } \\
\text { eral products }\end{array}$ & $(0.027)$ & $(0.044)$ & $(0.041)$ & 604 & 79 & 0.53 & Yes \\
\hline $\mathrm{C} 24$ basic metals & $\begin{array}{l}0.324 * * * \\
(0.027)\end{array}$ & $\begin{array}{l}0.070^{* * *} \\
(0.024)\end{array}$ & $\begin{array}{l}0.577 * * * \\
(0.013)\end{array}$ & 366 & 46 & 0.26 & Yes \\
\hline $\begin{array}{l}\text { C25 fabricated } \\
\text { metal products }\end{array}$ & $\begin{array}{l}0.498 * * * \\
(0.008)\end{array}$ & $\begin{array}{l}0.032 \\
(0.025)\end{array}$ & $\begin{array}{l}0.377 * * * \\
(0.004)\end{array}$ & 3956 & 550 & 0.00 & Yes \\
\hline $\begin{array}{l}\text { C26 computer, } \\
\text { electronic, } \\
\text { optical prod- } \\
\text { ucts }\end{array}$ & $(0.012)$ & $(0.022)$ & (0.024) & 652 & 81 & 0.00 & Yes \\
\hline $\begin{array}{c}\text { C27 electrical } \\
\text { equipment }\end{array}$ & $\begin{array}{l}0.339 \\
(0.278)\end{array}$ & $\begin{array}{l}0.103 \\
(0.089)\end{array}$ & $\begin{array}{l}0.508 \\
(0.427)\end{array}$ & 736 & 95 & 1.00 & Yes \\
\hline C28 machinery & $\begin{array}{l}0.317 * * * \\
(0.003)\end{array}$ & $\begin{array}{l}0.036 \text { *** } \\
(0.006)\end{array}$ & $\begin{array}{l}0.602^{* * * *} \\
(0.001)\end{array}$ & 1,665 & 203 & 0.00 & Yes \\
\hline $\begin{array}{l}\text { C29 motor vehi- } \\
\text { cles, trailers, } \\
\text { semi-trailers }\end{array}$ & $\begin{array}{l}0.326^{* * *} \\
(0.006)\end{array}$ & $(0.011)$ & $\begin{array}{l}0.615^{* * * *} \\
(0.006)\end{array}$ & 397 & 54 & 0.00 & No \\
\hline $\begin{array}{l}\mathrm{C} 30 \text { other trans- } \\
\text { port equipment }\end{array}$ & $\begin{array}{l}\text { NA } \\
\text { NA }\end{array}$ & $\begin{array}{l}\text { NA } \\
\text { NA }\end{array}$ & $\begin{array}{l}\text { NA } \\
\text { NA }\end{array}$ & 99 & 15 & NA & No \\
\hline C31 furniture & $\begin{array}{l}0.303 * * * \\
(0.009)\end{array}$ & $\begin{array}{l}0.023 * * * \\
(0.001)\end{array}$ & $\begin{array}{l}0.554 * * * \\
(0.016)\end{array}$ & 716 & 95 & 0.00 & Yes \\
\hline $\begin{array}{l}\text { C32 other manu- } \\
\text { facturing }\end{array}$ & $\begin{array}{l}0.422 * * * \\
(0.041)\end{array}$ & $\begin{array}{l}0.036^{*} \\
(0.018)\end{array}$ & $\begin{array}{l}0.429 * * * \\
(0.043)\end{array}$ & 332 & 42 & 0.19 & No \\
\hline $\begin{array}{l}\text { C33 repair, } \\
\text { installation }\end{array}$ & $\begin{array}{l}0.608 * * * \\
(0.046)\end{array}$ & $\begin{array}{l}-0.044 \\
(0.072)\end{array}$ & $\begin{array}{l}0.324 * * * \\
(0.050)\end{array}$ & 671 & 111 & 0.00 & Yes \\
\hline
\end{tabular}

All elasticities are cluster bootstrapped at the firm-level. Firms with negative or zero output and input amounts are automatically dropped by using logged variables.

${ }^{*} p<0.1 ;{ }^{* *} p<0.05 ;{ }^{* * *} p<0.01$ 
Acknowledgements I would like to thank Marina Di Giacomo (University of Turin), Hubert Fallmann (Environment Agency Austria), Marit Hinnosaar (University of Nottingham), and Marcos GonzalezAlvarez (European Commission, Directorate-Generale for Climate Action) for their support. Additionally, I want to thank the participants at the EBES conference and Collegio Carlo Alberto PhD-forum, especially Ender Demir (Istanbul Medeniyet University), Ralph Sonenshine (American University, Washington DC), Davide Vannoni (University of Turin), and Wolfgang Nagl (TH Deggendorf) for their helpful comments.

Funding Open access funding provided by Università degli Studi di Torino within the CRUI-CARE Agreement.

Open Access This article is licensed under a Creative Commons Attribution 4.0 International License, which permits use, sharing, adaptation, distribution and reproduction in any medium or format, as long as you give appropriate credit to the original author(s) and the source, provide a link to the Creative Commons licence, and indicate if changes were made. The images or other third party material in this article are included in the article's Creative Commons licence, unless indicated otherwise in a credit line to the material. If material is not included in the article's Creative Commons licence and your intended use is not permitted by statutory regulation or exceeds the permitted use, you will need to obtain permission directly from the copyright holder. To view a copy of this licence, visit http://creativecommons.org/licen ses/by/4.0/.

\section{References}

Ackerberg DA, Caves K, Frazer G (2015) Identification properties of recent production function estimators. Econometrica 83(6):2411-2451. https://doi.org/10.3982/ECTA13408

Aghion P, Bloom N, Blundell R, Griffith R, Howitt P (2005) Competition and innovation: an inverted-U relationship. Quart J Econ 120(2):701-728. https://doi.org/10.1093/qje/120.2.701

Aghion P, Cai J, Dewatripont M, Du L, Harrison A, Legros P (2015) Industrial policy and competition. Am Econ J Macroecon 7(4):1-32. https://doi.org/10.1257/mac.20120103

Arnold JM, Javorcik B, Mattoo A (2011) Does service liberalization benefit manufacturing firms: evidence from the Czech Republic. J Int Econ 85:136-146. https://doi.org/10.1016/j.jinteco.2011.05.002

Atayde R, Garduño R, Robles E, Zúñiga P (2021) Market competition and firm productivity and innovation: responses in Mexican manufacturing industries. Regional Sci Policy Practice 1-30. https://doi. org/10.1111/rsp3.12417

Aziz N, Hossain B, Lamb L (2021) Does green policy pay dividends? Environ Econ Policy Stud. https:// doi.org/10.1007/s10018-021-00317-7

Baghdasaryan D, la Cour L (2013) Competition, ownership and productivity. A panel analysis of Czech firms. J Econ Business 69:86-100. https://doi.org/10.1016/j.jeconbus.2013.06.002

Broberg T, Marklund P-O, Samakovlis E, Hammar H (2013) Testing the Porter hypothesis: the effects of environmental investments on efficiency in Swedish industry. J Prod Anal 40:43-56. https://doi.org/ 10.1007/s11123-012-0335-6

Bureau van Dijk (2007) Orbis: internet user guide

Castelnovo P, Del Bo CF, Florio M (2019) Quality of institutions and productivity of state-invested enterprises: international evidence from major telecom companies. Eur J Polit Econ 58:102-117. https:// doi.org/10.1016/j.ejpoleco.2018.10.005

Collard-Wexler A, De Loecker J (2015) Reallocation and technology: evidence from the US Steel Industry. Am Econ Rev 105(1):131-171. https://doi.org/10.1257/aer.20130090

Commins N, Lyons S, Schiffbauer M, Tol RSJ (2011) Climate policy and corporate behavior. Energy J 32(4):51-68. https://doi.org/10.2307/41323333

Copeland BR, Taylor MS (2004) Trade, growth and the environment. J Econ Lit 42:7-71. https://doi.org/ $10.1257 / 002205104773558047$

Crinò R, Epifani P (2012) Productivity, quality and export behaviour. Econ J 122:1206-1243. https://doi. org/10.1111/j.1468-0297.2012.02529.x

De Loecker J (2007a) Do exports generate higher productivity? Evidence from Slovenia. J Int Econ 73:69-98. https://doi.org/10.1016/j.jinteco.2007.03.003 
De Loecker J (2007b) Product differentiation, multi-product firms and estimating the impact of trade liberalization on productivity. NBER Working Papers 13155, pp 1-51

De Loecker J, Goldberg PK (2014) Firm performance in a global market. Annu Rev Econ 6:201-227. https://doi.org/10.1146/annurev-economics-080113-104741

De Loecker J, Warzynski F (2012) Markups and firm-level export status. Am Econ Rev 102(6):24372471. https://doi.org/10.2307/41724661

Del Bo CF (2013) Productivity in electricity generation: the role of firm ownership and regional institutional quality. Int Rev Appl Econ 27(2):237-264. https://doi.org/10.1080/02692171.2012.734792

Doraszelski U, Jaumandreu J (2013) RD and productivity: estimating endogenous productivity. Rev Econ Stud 80:1338-1383. https://doi.org/10.1093/restud/rdt011

Du L, Harrison A, Jefferson G (2014) FDI spillovers and industrial policy: the role of tariffs and tax holidays. World Dev 64:366-383. https://doi.org/10.1016/j.worlddev.2014.06.005

Enevoldsen M, Ryelund A, Andersen MS (2007) The impact of energy taxes on competitiveness, output and exports: a panel regression study of 56 European sectors. Work Package 3 in Competitiveness Effects of Environmental Tax Reforms. Final report to the European Commission, DG Research and DG Taxation and Customs Union, pp 177-197

Eurostat. 2020. Environmental taxes by economic activity (NACE Rev. 2). https://ec.europa.eu/euros tat/cache/metadata/en/env_ac_taxind2_esms.htm\#unit_measure1591345096289. Accessed 13 September 2020

Krukowska E (2020) Here's how the EU could tax carbon around the world. bloomberg green. 18.02.2020. https://www.bloomberg.com/news/articles/2020-02-18/here-s-how-the-eu-couldtax-carbon-around-the-world-quicktake. Accessed 2 Aug 2020

Fons-Rosen C, Kalemli-Ozcan S, Sorensen BE, Villegas-Sanchez C, Volosovych V (2021) Quantifying productivity gains from foreign investment. J Int Econ 131:103456. https://doi.org/10.1016/j. jinteco.2021.103456

Franco C, Marin G (2017) The effect of within-sector, upstream and downstream environmental taxes on innovation and productivity. Environ Resour Econ 66:261-291. https://doi.org/10.1007/ s10640-015-9948-3

Fujii H, Cao J, Managi S (2016) Firm-level environmentally sensitive productivity and innovation in China. Appl Energy 184:915-925. https://doi.org/10.1016/j.apenergy.2016.06.010

Gemmell N, Kneller R, McGowan D, Sanz I, Sanz-Sanz J (2018) Corporate taxation and productivity catch-up: evidence from European firms. Scand J Econ 120(2):372-399. https://doi.org/10.1111/ sjoe. 12212

Henderson D, Millimet D (2005) Environmental regulation and US state-level production. Econ Lett 87(1):47-53. https://doi.org/10.1016/j.econlet.2004.08.013

Higón DA, Antolín MM (2012) Multinationality, foreignness and institutional distance in the relation between R D and productivity. Res Policy 41:592-601. https://doi.org/10.1016/j.respol.2011.12. 007

Inui T, Kawakami A, Miyagawa T (2012) Market competition, differences in technology, and productivity improvement: an empirical analysis based on Japanese manufacturing firms. Jpn World Econ 24:197-206. https://doi.org/10.1016/j.japwor.2012.04.002

Javorcik BS (2004) Does foreign direct investment increase the productivity of domestic firms? in search of spillovers through backward linkages. Am Econ Rev 94(3):605-627. https://doi.org/10. $1257 / 0002828041464605$

Javorcik BS, Li Y (2013) Do the biggest aisles serve a brighter future? Global retail chains and their implications for Romania. J Int Econ 90:348-363. https://doi.org/10.1016/j.jinteco.2012.12.004

Klette Tor J, Griliches Z (1996) The inconsistency of common scale estimators when output prices are unobserved and endogenous. J Appl Econometr 11(4):343-361

Lanoie P, Patry M, Lajeunesse R (2008) Environmental regulation and productivity: testing the porter hypothesis. J Product Anal 30:121-128. https://doi.org/10.1007/s11123-008-0108-4

Leiter AM, Parolini A, Winner H (2011) Environmental regulation and investment: evidence from European industry data. Ecol Econ 70(4):759-770. https://doi.org/10.1016/j.ecolecon.2010.11. 013

Levine O, Warusawitharana M (2021) Finance and productivity growth: firm-level evidence. J Monet Econ 117:91-107

Levinsohn J, Petrin A (2003) Estimating production functions using inputs to control for unobservables. Rev Econ Stud 70:317-341. https://doi.org/10.1111/1467-937X.00246 
Lu Y, Linhui Y (2015) Trade liberalization and markup dispersion: evidence from Chinas WTO accession. Am Econ J Appl Econ 7(4):221-253. https://doi.org/10.1257/app.20140350

Lundgren T, Marklund P-O, Samakovlis E, Zhou W (2015) Carbon prices and incentives for technological development. J Environ Manage 150:393-403. https://doi.org/10.1016/j.jenvman.2014.12.015

Managi S, Opaluch JJ, Jin D, Grigalunas TA (2005) Environmental regulations and technological change in the offshore oil and gas industry. Land Econ 81(2):303-319. https://doi.org/10.3368/le.81.2.303

Martin R, de Preux LB, Wagner UJ (2014) The impact of a carbon tax on manufacturing: evidence from microdata. J Public Econ 117:1-14. https://doi.org/10.1016/j.jpubeco.2014.04.016

Newman C, Rand J, Talbot T, Tarp F (2015) Technology transfers, foreign investment and productivity spillovers. Eur Econ Rev 76:168-187. https://doi.org/10.1016/j.euroecorev.2015.02.005

Nishitani K, Kaneko S, Komatsu S, Fujii H (2014) How does a firms management of greenhouse gas emissions influence its economic performance? Analyzing effects through demand and productivity in Japanese manufacturing firms. J Product Anal 42:355-366

Norregaard, J, Reppelin-Hill V (2000) Taxes and tradable permits as instruments for controlling pollution: theory and practice. IMF working paper, WP/00/13, 1-50

Olley GS, Pakes A (1996) The dynamics of productivity in the telecommunications equipment sector. Econometrica 64(6):1263-1297. https://doi.org/10.2307/2171831

Olper A, Curzi D, Raimondi V (2016) Imported intermediate inputs and firms productivity growth: evidence from the food industry. J Agric Econ 68(1):280-300. https://doi.org/10.1111/1477-9552.12164

Ornaghi C (2006) Assessing the effect of measurement errors on the estimation of production functions. J Appl Econ 21(6):879-891. https://doi.org/10.1002/jae.887

Pigou AC (1920) The economics of welfare, 1st edn. Palgrave Macmillan, London

Porter ME (1991) Americas green strategy. Sci Am 264(4):168

Porter ME, Van der Linde C (1995) Towards a new conception of the environment-competitiveness relationship. J Econ Perspect 9(4):97-118. https://doi.org/10.1257/jep.9.4.97

Richter PM, Schiersch A (2017) CO2 emission intensity and exporting: evidence from firm-level data. Eur Econ Rev 98:373-391. https://doi.org/10.1016/j.euroecorev.2017.07.011

Syverson C (2011) What determines productivity? J Econ Literature 49(2):326-365. https://doi.org/10. 1257/jel.49.2.326

UBA (2013a) Chemische Erzeugnisse und Raffinerien, engl.: chemical products and refineries. Environmental Agency Germany. 15.09.2013. https://www.umweltbundesamt.de/themen/wirtschaft-konsum/industriebranchen/chemische-erzeugnisse-raffinerien. Last access: 15.07.2021

UBA (2013b) Glas- und Mineralfaserindustrie, engl.: glass and mineral fibre industry. Environmental Agency Germany. 13.08.2013. https://www.umweltbundesamt.de/themen/wirtschaft-konsum/indus triebranchen/mineralindustrie/glas-mineralfaserindustrie\#struktur-der-glas-und-mineralfaserind ustrie. Last access: 15.07.2021

UBA (2013c) Nahrungsmittelindustrie, engl.: food industry. Environmental Agency Germany. 18.07.2013. https:/www.umweltbundesamt.de/themen/wirtschaft-konsum/industriebranchen/nahrungs-futtermitt elindustrie-tierhaltungsanlagen/nahrungsmittelindustrie\#allgemeines. Last access: 15.07.2021

UBA (2013d) Nichteisenmetallindustrie, engl.: non-metallic metals industry. Environmental Agency Germany. 18.07.2013. https://www.umweltbundesamt.de/themen/wirtschaft-konsum/industriebranchen/ herstellung-verarbeitung-von-metallen/nichteisenmetallindustrie\#die-nichteisenmetallindustrie-indeutschland. Last access: 15.07.2021

UBA (2014) Holzindustrie, engl.: wood industry. Environmental Agency Germany. 24.09.2014. https:// www.umweltbundesamt.de/themen/wirtschaft-konsum/industriebranchen/holz-zellstoff-papierindu strie/holzindustrie. Last access: 15.07.2021

UBA (2019) Textilindustrie, engl.: textile industry. Environmental Agency Germany. 23.05.2019. https:// www.umweltbundesamt.de/themen/wirtschaft-konsum/industriebranchen/textilindustrie\#die-texti lindustrie-in-deutschland. Last access: 15.07.2021

Van Reenen J (2011) Does competition raise productivity through improving management quality? Int J Ind Organ 29:306-316. https://doi.org/10.1016/j.ijindorg.2011.02.001

Yang M, Yuan Y, Yang F, Patino-Echeverri D (2021) Effects of environmental regulation on firm entry and exit and China's industrial productivity: a new perspective on the Porter Hypothesis. Environ Econ Policy Stud. https://doi.org/10.1007/s10018-021-00310-0

Publisher's Note Springer Nature remains neutral with regard to jurisdictional claims in published maps and institutional affiliations. 